\title{
A Financing-Based Misvaluation Factor and the Cross-Section of Expected Returns
}

\author{
David Hirshleifer \\ Paul Merage School of Business, University of California at Irvine
}

Danling Jiang

College of Business, The Florida State University

\begin{abstract}
Behavioral theories suggest that investor misperceptions and market mispricing will be correlated across firms. We use equity and debt financing to identify common misvaluation across firms. A zero-investment portfolio (UMO, undervalued minus overvalued) built from repurchase and issue firms captures comovement in returns beyond that in some standard multifactor models, and substantially improves the Sharpe ratio of the tangency portfolio. Loadings on UMO incrementally predict the cross-section of returns on both portfolios and individual stocks, even among firms not recently involved in external financing activities. Further evidence suggests that UMO loadings proxy for the common component of a stock's misvaluation. (JEL G12, G14)
\end{abstract}

Several recent behavioral models predict commonality in the misvaluation of firms. In the style investing approach of Barberis and Shleifer (2003), commonality in misvaluation arises when irrational investor enthusiasm for stock characteristics shifts, inducing positive comovement among stocks with similar characteristics and negative comovement in stocks with dissimilar characteristics. In the overconfidence approach of Daniel, Hirshleifer, and Subrahmanyam (2001), investors misinterpret what they perceive to be private information

\footnotetext{
The article was previously entitled "Equity Financing, Commonality in Misvaluation, and the Cross-Section of Stock Returns." We appreciate helpful comments and suggestions from James Ang, Alex Butler, Karl Diether, Bing Han, Jean Helwege, Kewei Hou, Jason Karceski, Andrew Karolyi, Pete Kyle, Sonya Lim, Dave Peterson, Christof Stahel, René Stulz, Bhaskaran Swaminathan, and Siew Hong Teoh; participants at the Seventh Maryland Finance Symposium, the American Finance Association meetings at New Orleans, Louisiana, the Western Finance Association meetings at San Diego, California, and the FMA meetings at Orlando, Florida; our discussants, respectively: Jay Ritter, Kent Daniel, Andriy Bodnaruk, and Denys Glushkov; and especially the editor, Alexander Ljungqvist, and an anonymous referee. We thank Jay Ritter for providing the new issue data, Evgeny Lyandres for the investment factor returns, Michael Ferguson for the leverage factor returns, Kenneth French for the four-factor returns and industry classifications, and SuJung Choi, Yong Rin Park, and Dave Weaver for helpful research assistance. Send correspondance to David Hirshleifer, Professor of Finance and Merage Chair in Business Growth, Paul Merage School of Business, University of California at Irvine, Irvine, CA 92697-3125; telephone: (949) 824-9955. E-mail: david.h@uci.edu; Danling Jiang, Assistant Professor, College of Business, The Florida State University. Room 314 RBA, 821 Academic Way, Tallahassee, FL 32306-1110; telephone: (850) 645-1519. E-mail: djiang@cob.fsu.edu.
}

(C) The Author 2010. Published by Oxford University Press on behalf of The Society for Financial Studies. All rights reserved. For Permissions, please e-mail: journals.permissions@oxfordjournals.org. doi:10.1093/rfs/hhq063

Advance Access publication August 23, 2010 
about the genuine economic factors influencing firms' profits. Thus, sets of stocks with similar loadings move together as information about factors arrives, is misinterpreted, and is later corrected.

Characteristics such as book-to-market can reflect both firm-specific mispricing or misvaluation of systematic economic factors. Thus, evidence that stock characteristics such as size, book-to-market, or momentum predict the cross-section of future returns does not resolve whether there is systematic or merely firm-specific mispricing. ${ }^{1}$

On theoretical grounds, either idiosyncratic or common mispricing could be predominant. There is less incentive to study an idiosyncratic payoff component than a common one such as the market, which suggests more mispricing in idiosyncratic corners of the market. ${ }^{2}$ On the other hand, in the model of Daniel, Hirshleifer, and Subrahmanyam (2001), in a frictionless market idiosyncratic mispricing can be arbitraged away using low-risk hedge portfolios; the mispricing of common factors remains. Style investors and overconfident investors may trade in ways that cause either idiosyncratic or common mispricing. ${ }^{3}$ Since there are arguments on both sides, it is useful to test whether mispriced stocks comove, and whether measures of sensitivity to factor mispricing can be used to predict the cross-section of stock returns.

External financing and repurchase decisions provide information that can help address these questions. Theoretical and empirical research suggests that corporate managers undertake financing decisions to exploit both firm-specific and common misvaluation. Models of financing in inefficient markets suggest that issuing or repurchasing mispriced stocks or bonds can benefit a firm's existing shareholders, and will predict future returns (Stein 1996; Daniel, Hirshleifer, and Subrahmanyam 1998). Evidence from equity or debt financing and long-run returns suggests that firms tend to issue equity or risky debt when they are overvalued, and to buy back equity or retire risky debt when they are undervalued (see Section 1.3).

In this article, we use external financing activities to identify commonality in stock misvaluation, or what we call factor mispricing, and test whether sensitivities to common movements in misvaluation predict the cross-section of asset returns. We define a misvaluation (or mispricing) factor as any statistical common factor in stock returns that is substantially correlated with the

\footnotetext{
1 Fama and French (1993) find that book-to-market and size effects are associated with common factors, and suggest a rational risk explanation. Carhart (1997) links the momentum effect to common factors. An additional literature refines, tests, and in some cases disputes the risk premium interpretation of the three- or four-factor model (e.g., Daniel and Titman 1997; Griffin and Lemmon 2002; and Hou, Peng, and Xiong 2007).

2 There is evidence that some anomalies are stronger within the idiosyncratic component of returns (Grundy and Martin 2001; Hou, Peng, and Xiong 2007).

3 Consistent with overconfidence, investors speculate based upon opposing beliefs in macroeconomic markets such as foreign exchange markets and CPI futures. More generally, there are market timers who place bets against each other based on their beliefs about market aggregates, and investors who look for speculative industry plays.
} 
common mispricing of individual stocks. Commonality in misvaluation can occur when investors misinterpret signals about a fundamental economic factor, or when there are shifts in investor sentiment about firm characteristics or "styles."

If firms undertake new issues or repurchases to exploit mispricing, such events should reflect information possessed by managers about stock overor underpricing (above and beyond other observable characteristics). So, new issue and repurchase firms should have extreme sensitivities to mispricing factors, causing them to comove (even after controlling for familiar characteristics-based factors). We therefore construct a misvaluation factor by going long on repurchase stocks and short on the new issue stocks. This misvaluation factor, which we call $U M O$ (undervalued minus overvalued), is predicted to have a nonnegligible positive variance, even after controlling for the market or other well-known factors.

We further hypothesize that the loadings of general firms (not just those that have recently engaged in issuance or repurchase) on $U M O$ are proxies for systematic underpricing, and therefore will positively predict future returns. To see why, consider for example an oil price factor that affects firms' cash flows, and suppose that at a given point in time investors irrationally expect oil prices to be low. Repurchasers at that time will tend to be firms that are undervalued, which occurs if their profits are positively sensitive to oil prices (e.g., a solar power product vendor), whereas equity issuers will tend to be firms that are overvalued because their profits are negatively sensitive to oil prices (e.g., an airline). Furthermore, the repurchaser, being underpriced, will load positively on $U M O$ and the issuer, being overpriced, will load negatively on UMO. In other words, the factor loading measures the degree to which an asset inherits mispricing from the mispriced factor.

Alternatively, common mispricing can be caused by shifts in investor sentiment associated with different investment styles. For example, if investors become enamored with high-tech firms, then repurchases will be common among undervalued low-tech firms, and new issues among high-tech firms. During such a time period, low-tech firms will tend to load positively on UMO because their returns are more highly correlated with the low-tech firms that are engaging in repurchases than with the high-tech firms that are engaging in new issue.

Both lines of reasoning imply that a firm that loads positively on the mispricing factor, $U M O$, will, on average, be undervalued. As a result, loadings on the mispricing factor will positively predict high subsequent returns as information about future fundamentals resolves.

Even in an efficient market, external financing can predict future returns. We therefore control for sets of benchmark factors that have sometimes been interpreted as reflecting rational risk premia, including the Fama-French factors, the momentum factor, the leverage factor (Ferguson and Shockley 2003), and the investment factor (Lyandres, Sun, and Zhang 2008); we also control for 
industry effects. ${ }^{4}$ These benchmark factors and/or the characteristics they are based upon may also reflect behavioral effects; ${ }^{5}$ the use of these benchmarks ensures that the $U M O$ effects we identify are not just a repackaging of other known effects.

We find substantial variance in the return of $U M O$ incremental to the benchmark factor model. Furthermore, other asset portfolios have non-zero loadings on $U M O$ even after controlling for the benchmark factors. These findings show that $U M O$ captures commonality in stock returns incremental to that of the benchmark factors.

The $U M O$ factor earns a high mean return, $11 \%$ per annum, and a high Sharpe ratio, 0.30, which is similar to that of the investment factor and higher than that of each of the other benchmark factors. Using factors that are adjusted for the Fama-French five sectors (Fama and French 1997), UMO delivers the highest Sharpe ratio (0.39) of all the factors we consider. Moreover, UMO increases the Sharpe ratio of the ex post tangency portfolio by about $75 \%$ relative to the Fama-French factors. Furthermore, regressing $U M O$ on the sets of benchmark factors yields significantly positive alphas of 6-9\% per annum, a strong abnormal performance relative to the benchmark.

We further show that at both the portfolio and the firm levels, assets with higher $U M O$ loadings on average earn higher subsequent returns. At the portfolio level, we estimate $U M O$ loadings from previous five-year monthly returns. At the firm level, we obtain $U M O$ loadings from two approaches that account for the transitory nature of firm-level mispricing. In one, we estimate $U M O$ loadings from daily returns of individual stocks over a shorter period, 12 months. In the other, we assign stocks the loadings of portfolios that are matched by relevant firm characteristics that are potentially related to mispricing, including size, book-to-market, and the external financing variable of Bradshaw, Richardson, and Sloan (2006).

In portfolio tests, $U M O$ loadings predict the cross-section of portfolio returns after controlling for the loadings on the benchmark factors, with an estimated $U M O$ premium of about $6-9 \%$ per annum. In firm-level tests, a hedge portfolio that is long the highest and short the lowest loading decile yields an annual abnormal return of $7-10 \%$ per year, and regression tests imply an abnormal return from $U M O$ loadings of over $15 \%$ per year. $U M O$ loadings have incremental power to predict returns after controlling for various firm

4 Section 1 of the online Technical Appendix also considers other controls, including the macroeconomic factors suggested by Eckbo, Masulis, and Norli (2000), the new three-factor by Chen and Zhang (2010), the FamaFrench factors purged of new issue firms (e.g., Loughran and Ritter 2000), and a factor based on the asset growth variable of Cooper, Gulen, and Schill (2008).

5 See, for example, Keim (1983), Loughran (1997), Baker and Wurgler (2002), Baker, Stein, and Wurgler (2003), Daniel, Hirshleifer, and Subrahmanyam (2005), and Polk and Sapienza (2009). 
characteristics. ${ }^{6}$ The marginal effect of $U M O$ loadings on the cross-section of returns is considerably higher than that of the above return predictors.

This evidence is consistent with the proposition that the financing decisions of managers contain information about common stock mispricing, above and beyond firm characteristics such as size and book-to-market equity. The finding that $U M O$ loadings have incremental power relative to other mispricing proxies is consistent with behavioral theories that imply that both covariances and characteristics will, in general, have incremental power to predict stock returns (Daniel, Hirshleifer, and Subrahmanyam 2005).

In a behavioral setting, loadings on the mispricing factor, $U M O$, are proxies for systematic underpricing. Overreactions to factor signals cause fundamental factors to become overpriced at certain times and underpriced at others, while shifts in investor sentiment lead investment styles to become "hot" or "cold" over time. As a result, stocks that load on the mispriced fundamental factors or style factors will inherit the factor under- and overpricing accordingly. Since $U M O$ is constructed to be long on underpriced factors and short on overpriced ones, $U M O$ loadings of individual stocks will shift signs to reflect the shifts in factor or style mispricing. Therefore, we expect $U M O$ loadings to mean-revert quickly, and to flip signs fairly frequently (as discussed in Section 3.1).

Empirically, we find that stock loadings on the $U M O$ factor are stable over much shorter periods than the loadings on several well-known proposed fundamental factors. Following Fama and French (1992), we estimate the preranking $U M O$ loadings for individual stocks using three to five years of monthly returns and the post-ranking loadings from portfolios constructed based on pre-ranking loadings. UMO loadings are much more likely to flip signs than loadings on the three factors. Furthermore, sorting stocks based on pre-ranking $U M O$ loadings creates little dispersion in the post-ranking period.

\section{Motivation and Hypotheses}

\subsection{Rational factor pricing models}

In rational factor pricing models such as the intertemporal CAPM, after controlling for factor loadings as risk proxies, no other publicly available information can be used to predict returns. For several possible reasons, equity financing may be correlated with risk. First, equity issuance decreases leverage (e.g., Eckbo, Masulis, and Norli 2000). This argument implies that leverage changes should explain the returns of new issue firms, and therefore (contrary to existing evidence) that new debt financing should precede high future stock returns.

6 We control for size, book-to-market equity, past returns, industry dummies, the external financing variable of Bradshaw, Richardson, and Sloan (2006), the net composite issuance variable of Daniel and Titman (2006), the asset growth variable of Cooper, Gulen, and Schill (2008), the investment-asset ratio of Lyandres, Sun, and Zhang (2008), the net operating asset variable of Hirshleifer, Hou, Teoh, and Zhang (2004), the operating accruals of Sloan (1996), and the abnormal capital investment variable of Titman, Wei, and Xie (2004). 
Second, a shift in a firm's loadings that decreases its risk premium/discount rate should cause it to increase planned investment (Berk, Green, and Naik 1999; Zhang 2005). This implies a greater need for financing, so firms that have issued to fund investment should have lower expected stock returns. This argument suggests that the ability of equity/debt issuance to predict returns should be explained by investment. ${ }^{7}$ Similarly, the ability of a financing factor to explain the cross-section of returns should be largely subsumed by an investment factor.

\subsection{Behavioral models}

We focus here upon the style investing model of Barberis and Shleifer (2003) and the overconfidence model of Daniel, Hirshleifer, and Subrahmanyam (2001). ${ }^{8}$ In the model of Barberis and Shleifer (2003), stocks comove with two factors: a market factor, which captures market-wide cash flows, and a style factor, which represents commonality in sentiment for styles of stocks (such as size, value versus growth, or high-tech versus low-tech). Investors shift between styles based on past relative performance. Accordingly, the demand for different kinds of stocks varies according to their sensitivity to different style factors and to past style performance. Stocks whose styles have performed well become overpriced, leading eventually to low returns. Therefore, this model predicts that common shifts in investor style investing cause commonality in mispricing.

In the model of Daniel, Hirshleifer, and Subrahmanyam (2001), overconfident investors overestimate signal precision and, accordingly, overreact to private signals about payoffs of economic factors. This creates mispricing of factor payoffs and all securities whose cash flows are derived from these factors. In equilibrium, securities that load heavily on mispriced factors will be more misvalued. Thus, systematic mispricing results from investors' biased interpretation of factor cash flow information and reflects overreaction to cash flow news about fundamental factors.

Both models imply excess return comovement among securities caused by common misvaluation and correction of such mispricing. Here we define excess comovement as comovement in stock returns that deviates (either positively or negatively) from the fundamentals-based comovement that would exist in an efficient market based upon common fundamental influences.

7 Both the leverage effect and the investment effect, however, can be caused by managers exploiting irrational market valuation. So, a correlation of external financing with investment does not preclude a behavioral explanation (Baker and Wurgler 2002; Baker, Stein, and Wurgler 2003; and Gilchrist, Himmelberg, and Huberman 2005).

8 Several other models also imply non-fundamental commonality in asset price movements. For example, the prospect theory model of Barberis, Huang, and Santos (2001) suggests that stocks comove when investors' risk attitudes shift in response to market returns. The model of Kyle and Xiong (2001) implies common shifts in asset prices due to the simultaneous liquidation of multiple assets by convergence traders, after wealth shocks. 
Systematic mispricing can be correlated with fundamental cash flow factors, but does not have to be.

A growing literature tests whether market inefficiency is a source of stock return comovement. ${ }^{9}$ An advantage of using issuance/repurchase to identify commonality in misvaluation is that the decision to issue or repurchase equity or debt, under existing behavioral theories, reflects the beliefs of management about whether the stock is mispriced. It therefore provides an overall measure of mispricing based on information not otherwise detectable to the econometrician.

\subsection{External financing}

Existing evidence suggests that the post-event long-run performance of new issues and repurchases reflects correction of mispricing. For example, firms that engage in IPOs and SEOs on average underperform standard benchmarks for three to five years subsequent to the issue (Loughran and Ritter 1995, 2000; Spiess and Affleck-Graves 1995; using a modified benchmark, Brav, Geczy, and Gompers 2000 concur for post-SEO but not post-IPO underperformance). Since overvalued firms will tend to have both overpriced equity and risky debt, overvalued firms should tend to issue risky debt to exploit mispricing, and their equity should subsequently underperform. ${ }^{10}$ Some recent studies further show that firm-level measures of net equity financing are negatively related to subsequent stock returns (e.g., Bradshaw, Richardson, and Sloan 2006; Daniel and Titman 2006; Pontiff and Woodgate 2008).

Furthermore, aggregate equity issuance is correlated with market valuations and can forecast aggregate returns (e.g., Ritter 1984; Loughran, Ritter, and Rydqvist 1994; Baker and Wurgler 2000; Lowry 2003). This is potentially consistent with equity issuance responding to sector- or market-wide mispricing. ${ }^{11}$

With respect to repurchase, Lakonishok and Vermaelen (1990) and Ikenberry, Lakonishok, and Vermaelen (1995) show that the stocks of firms that buy back shares on average overperform in the subsequent three years. Similarly, the stocks of firms that reduce the outstanding debt in the face of market

9 See Lee, Shleifer, and Thaler (1991), Barberis, Shleifer, and Wurgler (2005), Goetzmann and Massa (2005), Baker and Wurgler (2006, 2007), Brown, Goetzmann, Hiraki, Shiraishi, and Watanabe (2008), Barber, Odean, and Zhu (2009), and Boyer (2010).

10 This is consistent with the evidence of Stigler (1964), Spiess and Affleck-Graves (1999), Bradshaw, Richardson, and Sloan (2006), and Cooper, Gulen, and Schill (2008). Overvaluation should cause greater issuance in total, and a substitution from debt to equity issuance. Baker and Wurgler (2000) test a hypothesis about substitution based on market timing of the relative mispricing of equity versus debt. However, debt and equity issuance are imperfect substitutes because of agency and tax considerations. So, despite the substitution effect, we do not expect the increase in total financing to be absorbed entirely by net equity issuance.

11 Schultz (2003) suggests that the long-term performance of new issues and repurchases may be a result of a pseudo-market-timing problem rather than market efficiency. However, a calendar-time portfolio approach as used in our article is immune to the pseudo-market-timing problem. 
undervaluation tend to overperform (e.g., Bradshaw, Richardson, and Sloan 2006).

Graham and Harvey (2001) find that a majority of CFOs say that stock mispricing is an important motive to issue equity. Consistent with market expectational errors, Jegadeesh (2000) documents that the stock market reacts unfavorably to earnings announcements subsequent to new issues. More generally, a rational risk-based explanation for the new issues puzzle seems to require that recent issuers have unusually low risk. It has not so far been established that new issue firms are a good hedge for aggregate consumption.

Our article differs from past work in this area in focusing on how general stocks comove with external-financing firms, and how covariance with a financing-based factor predicts future returns.

\subsection{Hypotheses}

We focus on the predictions of behavioral models, with the predictions of rational factor pricing as alternatives. Specifically, we hypothesize that a misvaluation factor $(U M O)$ that is long on repurchase stocks (undervalued) and short on new issue stocks (overvalued) will capture comovement associated with mispricing, and that an asset's loading on $U M O$ will positively predict future returns. Section 3 of the online Technical Appendix formally derives the predictions discussed informally here in a model based on the approach of Daniel, Hirshleifer, and Subrahmanyam (2001). These hypotheses, however, are intuitive and would apply in other behavioral modeling specifications as well.

Prediction 1. There is incremental comovement in stock returns associated with UMO above and beyond that implied by benchmark factors.

If there is commonality in mispricing, we expect mispricing to be shared by stocks (including those not involved with recent financing and payout activities) that load on the same mispriced fundamental factors, or that possess mispriced style characteristics. In either case, such stocks will comove with the misvaluation factor, $U M O$, even after controlling for proxies for possible fundamental factors.

Prediction 2. UMO will earn abnormally high returns relative to the benchmark factors.

Since $U M O$ is designed to capture the spread between under- and overpriced stocks, it is predicted to produce abnormal returns relative to common risk factors. In other words, we expect $U M O$ to have a high Sharpe ratio, and to earn a significant alpha in a regression on the benchmark factors. 
Prediction 3. The loadings on UMO will forecast the cross-section of stock returns.

Under our prediction that $U M O$ captures comovement in returns incrementally to benchmark factors, we hypothesize that securities' loadings on $U M O$ measure the degree of underpricing deriving from common factors (membership in misvalued sectors, or style effects). A positive loading identifies the influence on the stock price of either underpriced fundamental factors, or underpriced style characteristics. When such underpricing is subsequently corrected, securities with higher $U M O$ loadings earn greater returns. Stocks that load positively on $U M O$ will behave like repurchase firms and outperform, while those loaded negatively on $U M O$ will behave like new issue firms and underperform. Thus, the loadings on $U M O$ forecast returns even on general stocks that have not recently been involved in equity financing transactions.

So long as issuance or repurchase is associated with some firm-specific mispricing, the amount of issuance or repurchase should predict returns even after controlling for the degree to which the firm partakes of common mispricing. We therefore predict that the amount of external equity and/or debt financing will predict returns even after controlling for the UMO loading (see Daniel, Hirshleifer, and Subrahmanyam 2005 for a model with an analogous prediction about book-to-market and $H M L$ loadings).

\section{Data}

Our sample includes common stocks traded on NYSE, AMEX, and NASDAQ from January 1970 to December 2008. We exclude utilities (SIC Codes between 4900 and 4949) and financials (SIC Codes between 6000 and 6999) since mispricing is more constrained among regulated industries. Stock returns and other trading information are from the Center for Research in Security Prices (CRSP). Accounting information is from Compustat from 1971 to 2008. Daily and monthly return series for the market factor $(M K T)$, the size factor $(S M B)$, and the book-to-market factor $(H M L)$; the momentum factor $(M O M)$; and the risk-free rates are from Kenneth French's website. The investment factor $(I N V)$ is defined as the return of low-investment firms minus that of high-investment firms. The leverage factor $(L E V)$ is the return of high-leverage firms minus that of low-leverage firms. ${ }^{12}$ The Appendix provides details of the construction of these two factors.

12 We use the monthly return series of the investment factor provided by Evgeny Lyandres up to December 2005 supplemented with data from January 2006 through December 2008. We use the monthly return series of the investment factor provided by Michael Ferguson up to December 2001 and supplement it with data from January 2002 through December 2008. Results are similar if we use our own data throughout the sample period. 


\subsection{Main sample}

Among the sample firms, we identify 7,985 initial public offerings (IPOs) and 7,110 seasoned equity offerings (SEOs) from new issue data provided by Jay Ritter through the end of 2004 for IPOs and the end of 2001 for SEOs, supplemented by data from the SDC Global New Issues dataset through December 2008. We require that an IPO appear in the CRSP file within six months of the offer date. For SEOs, we exclude unit offerings and pure secondary offerings. From the SDC Global New Issues dataset, we identify 6,734 debt offerings (DISSUEs), including both straight and convertible debt, among the sample firms. We require SEOs and DISSUEs to have valid returns at the end of the offer month in CRSP. The annual number of firms is reported in Table 1.

Also in Table 1, altogether we identify 20,173 equity repurchase (ERP) events and 43,849 debt repurchase (DRP) events from Compustat annual statements. ERP is defined as occurring when net equity repurchases in a given fiscal year exceed $1 \%$ of average total assets. DRP occurs when a net long-term debt reduction in a given fiscal year exceeds $1 \%$ of average total assets. The net equity repurchase is total repurchase minus total issuance of common stocks. Total repurchase of common stocks is the purchase of common and preferred stocks (Compustat variable PRSTKC) less any decrease in preferred stocks. Total issuance of common stocks is the sale of common and preferred stocks $(S S T K)$ less any increase in preferred stocks. We measure preferred stocks as, in order of preference, the redemption value $(P S T K R V)$, the liquidating value $(P S T K L)$, or the carrying value $(P S T K)$. Long-term debt reduction is defined as long-term debt reduction (DLTR) minus long-term debt issuance (DLTIS) from the cash flow statement.

The main findings of the article are similar if we identify IPO events as the first appearance in CRSP, if we use cash flow statement information to identify equity and/or debt issuance, if we change the cutoff of the equity/debt issuance or repurchase as a fraction of the total assets to as low as $0 \%$ or as high as $5 \%$, if we obtain equity repurchase events (both open market and tender offer repurchases) from SDC, or if we restrict the sample of SEOs to primary offerings.

\subsection{Key variables}

At the end of June of each year, the portfolio "O" (overpriced) contains firms with IPOs, SEOs, and DISSUEs in the past 24 months if they had no ERPs or DRPs in the two most recent fiscal years ending as of the preceding December. The portfolio "U" (undervalued) contains firms with DRPs or ERPs in the two most recent fiscal years ending as of the preceding December if they had no IPOs, SEOs, or DISSUEs in the preceding 24 months. We require a gap of at least six months between fiscal year-end and the time of portfolio formation to ensure that repurchases by then are public information. Prior literature shows that the long-run abnormal performance of new issues and repurchases 
Table 1

Number of firms with events and in event portfolios

\begin{tabular}{|c|c|c|c|c|c|c|c|c|}
\hline Year & IPOs & SEOs & DISSUEs & ERPs & DRPs & $\mathrm{O}$ & $\mathrm{N}$ & $\mathrm{U}$ \\
\hline$\overline{1970}$ & 3 & 39 & 25 & & & & & \\
\hline 1971 & 12 & 123 & 44 & 68 & 430 & & & \\
\hline 1972 & 19 & 87 & 21 & 93 & 525 & 193 & 1477 & 419 \\
\hline 1973 & 184 & 37 & 6 & 307 & 769 & 340 & 3193 & 761 \\
\hline 1974 & 4 & 19 & 6 & 224 & 839 & 209 & 2527 & 1204 \\
\hline 1975 & 11 & 48 & 12 & 212 & 1127 & 51 & 2241 & 1496 \\
\hline 1976 & 26 & 72 & 17 & 246 & 1230 & 105 & 2068 & 1664 \\
\hline 1977 & 21 & 41 & 10 & 324 & 926 & 120 & 1883 & 1805 \\
\hline 1978 & 30 & 74 & 13 & 278 & 828 & 83 & 1880 & 1692 \\
\hline 1979 & 49 & 75 & 15 & 326 & 860 & 133 & 2004 & 1489 \\
\hline 1980 & 110 & 225 & 69 & 277 & 961 & 201 & 2018 & 1428 \\
\hline 1981 & 300 & 220 & 62 & 274 & 1028 & 484 & 2075 & 1407 \\
\hline 1982 & 81 & 170 & 53 & 329 & 1067 & 597 & 2008 & 1421 \\
\hline 1983 & 506 & 481 & 152 & 296 & 1301 & 575 & 2122 & 1482 \\
\hline 1984 & 307 & 95 & 143 & 441 & 1191 & 965 & 2139 & 1486 \\
\hline 1985 & 224 & 191 & 273 & 472 & 1168 & 768 & 2111 & 1569 \\
\hline 1986 & 410 & 225 & 415 & 473 & 1245 & 664 & 2186 & 1642 \\
\hline 1987 & 401 & 203 & 274 & 632 & 1389 & 969 & 2142 & 1584 \\
\hline 1988 & 146 & 84 & 155 & 719 & 1361 & 756 & 2074 & 1755 \\
\hline 1989 & 146 & 139 & 178 & 555 & 1325 & 398 & 1949 & 2012 \\
\hline 1990 & 153 & 128 & 163 & 618 & 1341 & 400 & 1890 & 1986 \\
\hline 1991 & 277 & 246 & 389 & 500 & 1541 & 399 & 1918 & 1917 \\
\hline 1992 & 404 & 312 & 362 & 458 & 1672 & 658 & 1859 & 1859 \\
\hline 1993 & 496 & 438 & 459 & 489 & 1686 & 783 & 2015 & 1809 \\
\hline 1994 & 489 & 291 & 268 & 556 & 1571 & 920 & 2295 & 1886 \\
\hline 1995 & 432 & 421 & 380 & 651 & 1482 & 844 & 2402 & 1950 \\
\hline 1996 & 701 & 505 & 381 & 691 & 1606 & 1008 & 2577 & 2012 \\
\hline 1997 & 453 & 364 & 366 & 845 & 1505 & 1190 & 2636 & 1961 \\
\hline 1998 & 264 & 231 & 453 & 1055 & 1276 & 986 & 2710 & 2009 \\
\hline 1999 & 414 & 285 & 272 & 1125 & 1230 & 706 & 2456 & 2066 \\
\hline 2000 & 366 & 287 & 201 & 986 & 1288 & 760 & 2185 & 2207 \\
\hline 2001 & 57 & 152 & 265 & 674 & 1239 & 621 & 1936 & 2084 \\
\hline 2002 & 61 & 107 & 233 & 630 & 1327 & 333 & 1844 & 2052 \\
\hline 2003 & 41 & 127 & 170 & 545 & 1173 & 192 & 1646 & 1980 \\
\hline 2004 & 137 & 141 & 100 & 547 & 1037 & 231 & 1578 & 1901 \\
\hline 2005 & 87 & 123 & 87 & 676 & 925 & 291 & 1649 & 1737 \\
\hline 2006 & 73 & 114 & 91 & 769 & 842 & 266 & 1686 & 1647 \\
\hline 2007 & 71 & 111 & 97 & 832 & 766 & 262 & 1617 & 1664 \\
\hline 2008 & 19 & 79 & 54 & 980 & 772 & 228 & 1524 & 1690 \\
\hline All & 7985 & 7110 & 6734 & 20173 & 43849 & 18689 & 76520 & 62733 \\
\hline Mean & 205 & 182 & 173 & 531 & 1154 & 505 & 2068 & 1695 \\
\hline
\end{tabular}

This table reports the number of event firms with initial public offerings (IPOs), seasoned equity offerings (SEOs), debt offerings (DISSUEs) (including both straight and convertible debt offerings), equity repurchases (ERPs), and debt repurchases (DRPs) for each year over the period 1970-2008, and the number of firms in the event portfolios O, N, and U in the beginning of July of each year from 1972 through 2008. At the end of June of each year, firms issuing IPOs, SEOs, or/and DISSUEs in the last 24 months but not involving stock repurchases during the most recent two fiscal years with the fiscal year ending as of last December are included in portfolio $\mathrm{O}$ (overpriced). Firms with ERPs or/and DRPs made during the most recent two fiscal years with the fiscal year ending as of last December but not issuing IPOs, SEOs, or/and DISSUEs in the last 24 months are included in portfolio $\mathrm{U}$ (underpriced). Firms that involve both equity/debt offerings and repurchases or neither of the two are included in portfolio $\mathrm{N}$ (neutral).

is concentrated in the first three years after events (e.g., Loughran and Ritter 1995; Ikenberry, Lakonishok, and Vermaelen 1995). We select firms based on events that have occurred in the preceding two years so that the event portfolio returns cover the period from one to three years following the event. Stocks 
with both equity issuance and repurchases or neither are included in portfolio "N" (neutral). ${ }^{13}$

The three equal-weighted portfolios are held from July of year $t$ to June of year $t+1$, and rebalanced. Following Fama and French (1993), we form a zeroinvestment portfolio " $U M O$ " (undervaluation minus overvaluation), which is long on $\mathrm{U}$ and short on $\mathrm{O}$, to capture the possible commonality in misvaluation. $^{14}$

To address the possibility that the performance of $U M O$ comes from industry-/sector-wide fundamental shocks (e.g., Hou 2007) that are not captured by the benchmark factors, we also consider a sector-neutral " $U M O_{\perp \mathrm{SEC}}$." To minimizes sectoral effects, we compute the equal-weighted returns among new issues separately within each of the five sectors, based on the Fama-French (1997) five industry classifications. Then we define the equal-weighted five sector returns as returns on $\mathrm{O}_{\perp \mathrm{SEC}}$. A similar procedure gives $\mathrm{U}_{\perp \mathrm{SEC}}$. Finally, $U M O_{\perp \mathrm{SEC}}$ is formed by going long on $\mathrm{U}_{\perp \mathrm{SEC}}$ and short on $\mathrm{O}_{\perp \mathrm{SEC}}$.

Table 2 reports summary statistics of the event portfolios, UMO, and the other well-known factor portfolios. Since cash flow statement information is widely available from 1971, the portfolio U starts from July 1972, which limits $U M O$ to the period starting from July 1972. As shown in Table 1, the average number of firms in July of each year is 505 for $\mathrm{O}$ and 1,695 in $\mathrm{U}$, showing that UMO contains a sizable number of stocks. ${ }^{15}$

Consistent with the previous literature, during our sample period, repurchase stocks $(\mathrm{U})$ on average outperform neutral $(\mathrm{N})$ stocks while neutral stocks $(\mathrm{N})$ on average outperform new issue stocks (O). UMO offers an average return of $0.93 \%$ per month, or over $11 \%$ per year, while $U M O_{\perp \text { SEC }}$ offers $0.92 \%$ per month. The two are highly correlated, with a coefficient of 0.91 as shown in Panel B of Table 2. Panel B also shows that $U M O$ has strong correlations with $M K T, H M L, M O M, I N V$, and $L E V$. In subsequent tests, we estimate loadings on $U M O$ by controlling for these benchmark factors. Thus, our finding that $U M O$ loadings are positive predictors of the cross-section of returns is not driven by these factor correlations.

13 Depending on the year, on average a fraction of about $14 \%$ of event firms (standard deviation $7.7 \%$ ) are excluded from portfolio $\mathrm{O}$ or $\mathrm{U}$ for being both issuers and repurchasers. Thus, an overwhelming fraction of event firms can be identified as either under- or overpriced unambiguously using the external financing events.

14 It is known that new issuers tend to be small-growth firms and repurchasers tend to be large-value firms. When constructing $U M O$, however, we did not control for size and book-to-market. This is because behavioral theories suggest that these characteristics reflect stock mispricing, and that equal weighting the returns across size or book-to-market groups can reduce the power to detect mispricing of new issues/repurchases (Loughran and Ritter 2000). Instead, our tests perform a horse race between $U M O$ and the size and book-to-market factors. We find that the power of $U M O$ to explain returns is not subsumed by the size or the book-to-market effect.

15 Although firms stay in $\mathrm{O}$ or $\mathrm{U}$ for a two-year period, the number of firms in $\mathrm{O}$ or $\mathrm{U}$ is less than twice the number of new-issue or repurchase firms. This is due to at least three effects. First, multiple types of equity/debt issues can occur for one firm and are counted in $\mathrm{O}$ as one stock. Second, both equity and debt repurchases can occur for the same firm during a two-year period and are counted in $\mathrm{U}$ as one stock. Third, some new-issue firms also have repurchases during a two-year window and thus do not enter $\mathrm{O}$ or $\mathrm{U}$. 
Table 2

Summary statistics of event and factor portfolios

Panel A: Portfolio returns

\begin{tabular}{|c|c|c|c|c|c|c|}
\hline & Mean & Std & $t$-stat & $S R$ & $M E$ & $B M$ \\
\hline $\bar{U}$ & 1.38 & 6.19 & 4.68 & 0.15 & 1049 & 0.88 \\
\hline$N$ & 1.06 & 6.64 & 3.33 & 0.09 & 1001 & 0.81 \\
\hline$O$ & 0.46 & 7.94 & 1.20 & 0.00 & 1323 & 0.52 \\
\hline$U M O$ & 0.93 & 3.08 & 6.30 & 0.30 & & \\
\hline$U M O_{\perp \mathrm{SEC}}$ & 0.92 & 2.39 & 8.11 & 0.39 & & \\
\hline$M K T$ & 0.37 & 4.61 & 1.69 & 0.08 & & \\
\hline$S M B$ & 0.17 & 3.24 & 1.11 & 0.05 & & \\
\hline$H M L$ & 0.48 & 3.04 & 3.31 & 0.16 & & \\
\hline MOM & 0.88 & 4.25 & 4.36 & 0.21 & & \\
\hline$I N V$ & 0.52 & 1.71 & 6.34 & 0.30 & & \\
\hline$L E V$ & 0.38 & 3.44 & 2.29 & 0.11 & & \\
\hline
\end{tabular}

Panel B: Correlation matrix of factor mimicking portfolios

\begin{tabular}{|c|c|c|c|c|c|c|c|}
\hline & $U M O$ & $U M O_{\perp \mathrm{SEC}}$ & $M K T$ & $S M B$ & $H M L$ & $M O M$ & $I N V$ \\
\hline$U M O_{\perp \mathrm{SEC}}$ & 0.91 & & & & & & \\
\hline$M K T^{\perp \mathrm{SLC}}$ & -0.53 & -0.48 & & & & & \\
\hline$S M B$ & -0.21 & -0.11 & 0.26 & & & & \\
\hline$H M L$ & 0.65 & 0.58 & -0.42 & -0.28 & & & \\
\hline$M O M$ & 0.22 & 0.17 & -0.10 & 0.01 & -0.13 & & \\
\hline$I N V$ & 0.37 & 0.32 & -0.29 & -0.12 & 0.19 & 0.19 & \\
\hline$L E V$ & 0.42 & 0.37 & -0.16 & 0.14 & 0.61 & -0.20 & 0.07 \\
\hline
\end{tabular}

Panel C: Ex post tangency portfolio

\begin{tabular}{|c|c|c|c|c|c|c|c|c|c|c|}
\hline & \multicolumn{7}{|c|}{ Portfolio Weights } & \multicolumn{3}{|c|}{ Tangency Portfolio } \\
\hline & $M K T$ & $S M B$ & $H M L$ & MOM & $I N V$ & $L E V$ & $U M O$ & Mean & Std & $S R$ \\
\hline (1) & 0.25 & 0.17 & 0.58 & & & & & 0.40 & 1.68 & 0.24 \\
\hline (2) & 0.20 & 0.11 & 0.43 & 0.27 & & & & 0.54 & 1.52 & 0.35 \\
\hline (3) & 0.15 & 0.08 & 0.20 & & 0.56 & & & 0.46 & 1.13 & 0.41 \\
\hline (4) & 0.25 & 0.20 & 0.65 & & & -0.10 & & 0.40 & 1.66 & 0.24 \\
\hline (5) & 0.28 & 0.09 & -0.02 & & & & 0.65 & 0.71 & 1.70 & 0.42 \\
\hline (6) & 0.25 & 0.08 & 0.07 & 0.13 & & & 0.47 & 0.69 & 1.57 & 0.44 \\
\hline (7) & 0.20 & 0.06 & 0.02 & & 0.40 & & 0.33 & 0.60 & 1.24 & 0.49 \\
\hline (8) & 0.28 & 0.12 & 0.07 & & & -0.11 & 0.64 & 0.71 & 1.67 & 0.43 \\
\hline
\end{tabular}

Panel A reports the summary statistics of the event portfolios and the factor portfolio percentage returns from July 1972 through December 2008. The event portfolios $U, N$, and $O$ are defined in Table 1. UMO (underpricing minus overpricing) is the misvaluation factor that is long on $U$ and short on $O$. $\mathrm{UMO}_{\perp \mathrm{SEC}}$ controls for the sector influences in $U M O$ by taking the average returns of new issues and repurchases within each of the five sectors before taking the mean returns across the five sectors. The five sectors are defined based on the Fama-French five industry classifications. $M K T, S M B$, and $H M L$ are the market, size, and book-to-market factors of Fama and French (1993). MOM is the momentum factor of Carhart (1997). INV is the investment factor of Lyandres, Sun, and Zhang (2008). $L E V$ is the leverage factor of Ferguson and Shockley (2003). The Sharpe ratio (SR) for $U, N$, and $O$ is the ratio of mean monthly returns in excess of the one-month risk-free rate divided by return standard deviation; for the factor portfolios, is the ratio of the mean monthly returns over return standard deviation. The variables $M E$ (in millions) and $B M$ are the average monthly market value and book-to-market equity of firms included in $U, N$, or $O$. Panel B reports the Pearson correlations among the factor portfolios. Panel $\mathrm{C}$ reports the summary statistics of the ex post tangency portfolio. The tangency portfolio correctly prices the candidate portfolios with non-zero weights and delivers the highest Sharpe ratio by optimally combining these candidate portfolios. The portfolio weights are calculated as $\left(l^{\prime} V^{-1} \mu\right)^{-1} V^{-1} \mu$, where $t$ is a $\mathrm{k} \times 1$ vector of ones, $V$ is the covariance matrix of the factor returns, and $\mu$ is the mean factor returns.

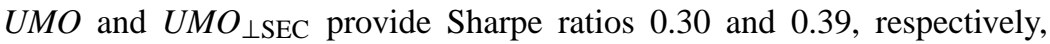
which are considerably greater than those of $M K T$ (0.08), SMB (0.05), HML (0.16), MOM (0.21), and LEV (0.11), and comparable to INV (0.30). To study 
the incremental contribution of UMO in improving the achievable Sharpe ratios, in Panel C in Table 2, we report the weights, returns, and Sharpe ratios of the ex post tangency portfolios calculated following MacKinlay (1995). The tangency portfolio generates the highest Sharpe ratio by optimally combining a subset of factors. Adding $U M O$ to the three factors increases the maximum Sharpe ratio from 0.24 to 0.42 , an increase close to $75 \%$. Adding $U M O$ to the three factors plus the momentum factor increases the Sharpe ratio from 0.35 to 0.44 . In both cases, the tangency portfolio places a substantial weight $(65 \%$ and $47 \%$ ) on $U M O$ as opposed to the other candidate factors.

Adding $U M O$ to the three factors greatly reduces the weight of $S M B$-from 0.17 to 0.09 - and essentially eliminates $H M L$ from the tangency portfolio-a reduction from 0.58 to -0.02 . This probably occurs because $U M O$ is rather highly correlated with $H M L(0.65)$, but delivers much higher expected returns with similar volatility. This suggests that $U M O$ is a better proxy than $H M L$ for misvaluation or for priced factors.

An improvement in the Sharpe ratio from adding $U M O$ is observed if we include $I N V$ or $L E V$ together with the three factors. The highest Sharpe ratio (0.49) is achieved by combining the three factors with INV and UMO. Across all cases, there is a perceptible reduction in the weights of $S M B$ and $H M L$. Overall, these results show that $U M O$ delivers an unusually large Sharpe ratio and is an important contributor to the ex post tangency portfolio.

\section{Comovement in returns and the $U M O$ factor}

We now test whether, as hypothesized, $U M O$ captures commonality in returns, and whether $U M O$ achieves abnormal returns relative to other benchmark factors.

\subsection{Loadings of assets on $\boldsymbol{U M O}$}

Prediction 1 implies return comovement. We first test for comovement by estimating the loadings of assets on $U M O$. If overpriced or underpriced general individual stocks load on some of the same mispriced fundamental factors that new issues and repurchase stocks load upon, or mispriced general stocks share some of the same style characteristics that cause mispricing in new issue and repurchase stocks, they will share incremental comovement with $U M O$ relative to the benchmark factors during the period that mispricing is created and later corrected. However, over a long time series, if overpricing and underpricing occur about equally often, we expect individual stocks to have loadings on UMO that are close to zero. ${ }^{16}$

16 In the example discussed in the introduction, when investors irrationally expect low oil prices, airlines are overpriced and tend to issue, while solar product vendors are underpriced and tend to repurchase. Accordingly, firms that benefit from low oil prices will load negatively, and those that are hurt will load positively, on UMO. However, if investor sentiment shifts to an irrational belief that the oil price will be high, the industries that are issuing versus repurchasing flip. In consequence, the loadings of other firms on $U M O$ reverse, which shows that the $U M O$ loadings of individual stocks are transitory. 
In contrast, we expect portfolios formed based on mispricing measures to have stable loadings on $U M O$ - positive among underpriced stocks and negative among overpriced stocks. When such portfolios are periodically rebalanced, stocks enter or exit the portfolios according to their degree of mispricing, which tends to stabilize the degree of mispricing in the portfolio (relative to individual stocks) and therefore the loadings of the portfolios on UMO. So, to test for return comovement with $U M O$, we examine portfolios that are rebalanced based upon firm characteristics that are potentially related to mispricing, such as size, book-to-market, and financing-based variables. These portfolios are rebalanced once every year to try to achieve similar degrees of under- or overpricing, and therefore similar loadings on $U M O$, over time.

Using the well-known Fama-French 25 size- $B M$ portfolios as an example, we regress value-weighted monthly returns of each portfolio on $U M O$ together with the Fama-French three factors and test whether $U M O$ loadings $\left(\beta_{u}\right)$ are jointly different from zero.

Panel A of Figure 1 plots the $U M O$ loadings across the size and book-tomarket sorts. Results based on $U M O_{\perp \mathrm{SEC}}$ or with alternative benchmark factors are similar. $U M O$ loadings do not line up monotonically with either size or BM. The $F$-statistic is $8.39(p=0.00)$, which strongly rejects the null that all $U M O$ loadings are jointly equal to zero.

We focus on the smallest and largest size groups because their comovement with $U M O$ differs sharply across the book-to-market quintiles. Among the smallest size group, UMO loadings increase with the book-to-market, while among the largest size group, the opposite pattern holds. In other words, smallgrowth and large-value firms tend to load negatively on $U M O$, while smallvalue and large-growth firms tend to load positively on $U M O$. This pattern of $U M O$ loadings is very similar to that of the Fama-French three-factor alphas reported in Panel B. The mispricing of the 25 portfolios relative to the threefactor model has a high correlation, 0.77, with $U M O$ loadings. This suggests that $U M O$ helps explain the pricing errors of the three-factor model.

In unreported tests, we find that $U M O$ indeed helps reduce and even eliminate pricing errors (alphas) in time-series regressions. In particular, when the three-factor model is used to price the 25 size- $B M$ portfolios, it is well known that substantial pricing errors are present among the four corner portfolios. When $U M O$ is additionally included, these pricing errors are visibly reduced and become insignificant for all but extreme small-growth portfolios. After adding $U M O$ to the three factors, the $F$-statistic that tests whether the alphas are jointly equal to zero no longer rejects that null. Moreover, we also find that, relative to the three-factor model, $U M O$ helps reduce the pricing errors of portfolios based on other corporate events that are known to produce abnormal long-run performances, such as mergers and acquisitions (Loughran and Vijh 1997), dividend initiation and resumption (Michaely, Thaler, and Womack 1995), and dividend omission (Boehme and Sorescu 2002). Overall, this evidence indicates that $U M O$ is important for pricing stocks with a variety of 

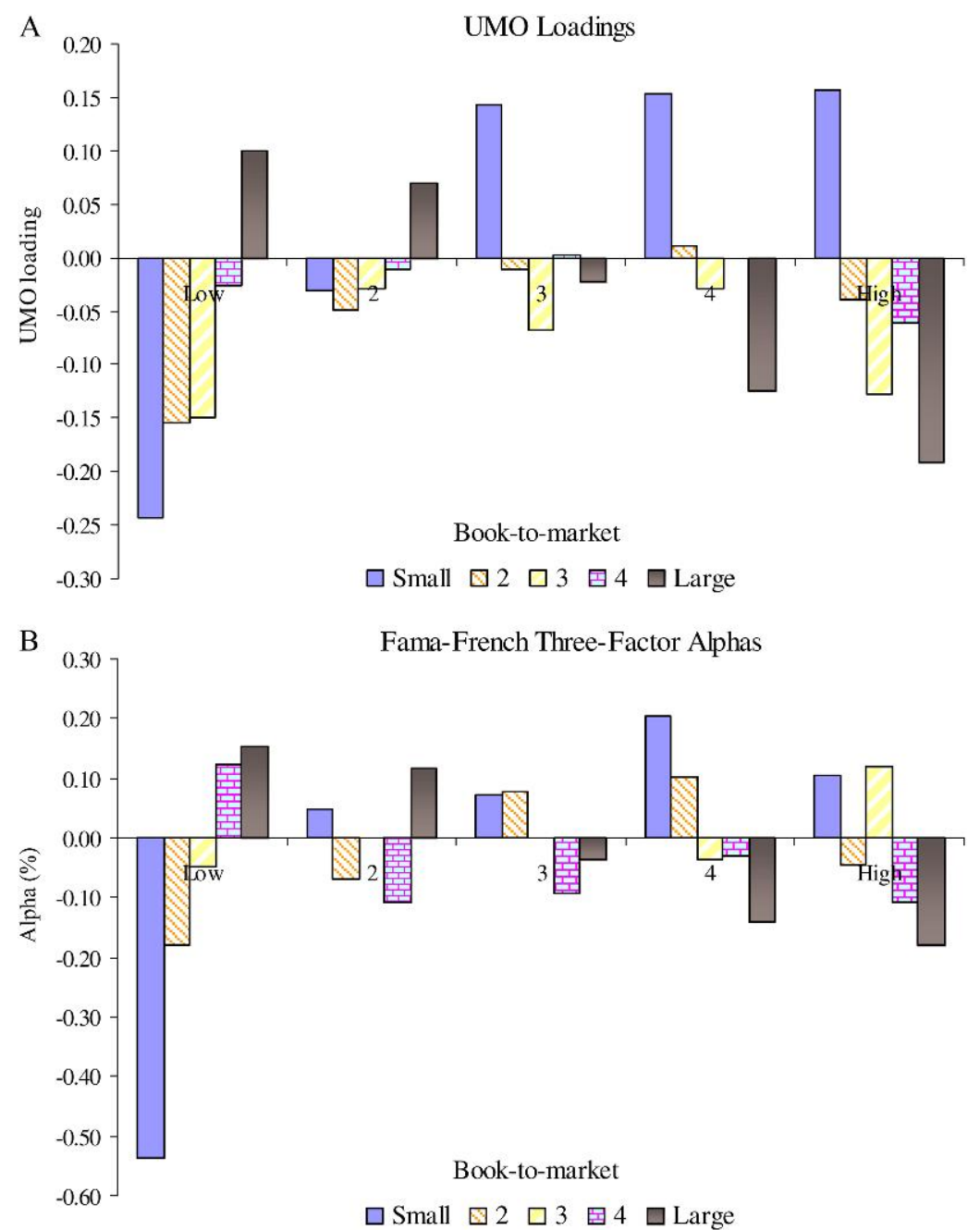

\section{Figure 1 \\ $U M O$ loadings and Fama-French three-factor alphas of the Fama-French 25 size-BM portfolios}

Panel A plots the slope coefficients on $U M O$ of regressions of excess monthly returns of the 25 valueweighted size- $B M$ portfolios on the misvaluation factor $U M O$ and the Fama-French three factors ( $M K T$, $S M B$, and $H M L$ ). Panel B plots the intercepts (alphas) of regressions of excess monthly returns of the 25 size- $B M$ portfolios on the Fama-French three factors. The two panels show strong similarity between $U M O$ loadings and abnormal returns of the 25 portfolios relative to the three factors, suggesting that $U M O$ is a source of three-factor model pricing errors of the 25 portfolios. The factors are defined in Table 2.

characteristics, and the anomalous returns on the corner portfolios and on other corporate-event based portfolios.

\section{2 $U M O$ and other factors}

We provide here a further test of whether $U M O$ is a source of comovement (Prediction 1) based solely on factor returns, and then test whether $U M O$ achieves abnormal returns (Prediction 2). 
In general, in a randomly formed, well-diversified, zero-investment portfolio, as the number of securities increases, both the loadings on underlying factors and idiosyncratic risk approach zero, so portfolio return variance also approaches zero. In contrast, Prediction 1 maintains that forming a long-short portfolio based upon firms' financing decisions causes loading on some underlying factor(s), resulting in substantial positive variance. So, residual variance is predicted to be substantial even after regressing on the benchmark factors, and specifically, to be greater than the residual variance of an equal-weighted long-short portfolio with randomly selected stocks.

To perform this comparison, we form a random long-side portfolio at the end of each June by randomly selecting a set of stocks equal to the number contained in portfolio $\mathrm{U}$, and similarly form a random short-side portfolio with a set of stocks equal to the number in portfolio $\mathrm{O}$. We equally weight the stocks on each side, and then form the long-short portfolio. We regress the returns of the randomly selected portfolio on a set of benchmark factors and compute the residual return standard deviation (volatility). This exercise is repeated 1,000 times to generate a distribution of the residual return volatility. We compare this with the residual return volatility from regressing $U M O$ on the same set of benchmark factors.

Consistent with Prediction 1, Table 3 shows that in the $U M O$ regressions the $R^{2}$ s are about $51-57 \%$, and the residual return standard deviations are about $2.00-2.16 \%$ per month. These are substantially larger than those based on randomly selected portfolios. The low $R^{2} \mathrm{~s}$ and high residual volatility suggest that new issue and repurchase stocks share incremental commonality above and

Table 3

Regressions of $\mathrm{UMO}$ on benchmark factors

\begin{tabular}{cccccccccc} 
& Intercept & $M K T$ & $S M B$ & HML & MOM & $I N V$ & LEV & $R^{2}$ & $\sigma(\epsilon)$ \\
\hline$(1)$ & 0.75 & -0.21 & 0.02 & 0.54 & & & & $51 \%$ & 2.16 \\
& $(7.19)$ & $(-5.92)$ & $(0.28)$ & $(7.82)$ & & & & & $(0.977,1.217)$ \\
$(2)$ & 0.53 & -0.18 & 0.02 & 0.59 & 0.20 & & & $57 \%$ & 2.00 \\
& $(5.12)$ & $(-5.73)$ & $(0.36)$ & $(10.31)$ & $(4.47)$ & & & & $(0.977,1.217)$ \\
$(3)$ & 0.56 & -0.18 & 0.03 & 0.52 & & 0.36 & & $54 \%$ & 2.08 \\
& $(5.22)$ & $(-5.48)$ & $(0.49)$ & $(8.89)$ & & $(3.50)$ & & & $(0.977,1.219)$ \\
$(4)$ & 0.75 & -0.21 & -0.01 & 0.47 & & & 0.08 & $51 \%$ & 2.15 \\
& $(7.35)$ & $(-5.95)$ & $(-0.15)$ & $(7.11)$ & & & $(1.45)$ & & $(0.977,1.219)$ \\
\hline
\end{tabular}

This table reports the time-series regression of $U M O$ on a set of benchmark factors from July 1972 through December 2008. The dependent variable is monthly percentage returns on $U M O$. The independent variables are the benchmark factors, including $M K T, H M L, S M B, M O M$, INV, and $L E V$, all defined in Table 2. Robust NeweyWest (1987) $t$-statistics are reported in parentheses. The $R^{2} \mathrm{~s}$ are adjusted for degree of freedom. The variable $\sigma(\epsilon)$ is the standard deviation of the regression error term. In parentheses underneath is the $1 \%$ confidence interval of the standard deviation of the residual terms based on long-short portfolios with randomly selected stocks. Specifically, we form portfolios with randomly selected stocks at the end of each June with the equal number of stocks as that in portfolio $\mathrm{U}$ in the long side and as that in portfolio $\mathrm{O}$ in the short side. Then we calculate the equal-weighted long-short portfolio returns. We regress the randomly selected portfolio returns on a set of benchmark factors and compute the standard deviation of the residual terms. This exercise is repeated 1,000 times to generate a distribution of the standard deviation, and we report the $1 \%$ confidence interval based on this distribution. An observed standard deviation of the residual terms from regressions of $U M O$ is statistically significant when it is above the right end of the confidence interval. 
beyond the comovement implied by the benchmark factors. This is consistent with $U M O$ capturing common misvaluation factors. However, this does not rule out the possibility that the commonality comes from fundamental sources not captured by the four factors.

This regression also provides a test of Prediction 2, abnormal performance of $U M O$. Consistent with Prediction 2, as shown in Table 3, the positive alphas, ranging from $0.53-0.75 \%$ per month, show that $U M O$ offers abnormally high returns (6.36-9.00\% per year) relative to the benchmark factors. This evidence confirms the findings of previous research of significant long-run overperformance associated with repurchases and underperformance associated with new issues.

As discussed in Section 1.1, the returns on firms with financing events may derive from a risk premium or misvaluation associated with a common factor in growth/investment opportunities. To address this possibility, in Section 1 of the online Technical Appendix, we consider other sets of benchmark factors, including the macroeconomic factors suggested by Eckbo, Masulis, and Norli (2000), the three-factor model of Chen and Zhang (2010), the Fama-French factors purged of new issue firms (e.g., Loughran and Ritter 2000), and a factor based on the asset growth variable of Cooper, Gulen, and Schill (2008). Even after controlling for models containing these additional factors, the $R^{2}$ of $U M O$ is still below $56 \%$. The residual volatility is around $2.05-2.33 \%$, substantially and significantly higher than the simulated residual volatility using random long-short portfolios over the same sample period.

\section{Do UMO Loadings Predict the Cross-Section of Asset Returns?}

We now test Prediction 3, that $U M O$ loadings predict the cross-section of future asset returns. Behavioral models predict that $U M O$ loadings are proxies for systematic undervaluation, and therefore will predict higher excess returns. We start by testing the ability of loadings on characteristic portfolios to predict returns, and then consider loadings on individual stocks.

\subsection{UMO loadings and the cross-section of portfolio returns}

$U M O$ loadings for individual stocks tend to be unstable over time. Intuitively, different styles or economic factors will be over- or underpriced at different times. Accordingly, a given loading of a stock on some style or economic factor will imply over- and undervaluation at different times. [Section 3 of the online Technical Appendix contains a proof of this assertion (see Proposition 2).] $U M O$ is always long on the underpriced factors and short on overpriced factors. Thus, we expect individual stocks, while having fairly persistent loadings on the style or economic factors, to have unstable loadings on UMO.

In contrast with individual stocks, portfolios that are formed based on possible mispricing proxies such as book-to-market should have much more stable $U M O$ loadings over time. Thus, we run a Fama-MacBeth regression with the 25 size- $B M$ portfolios and test whether $U M O$ carries a significant positive 
Table 4

Fama-MacBeth regressions at the portfolio level

\begin{tabular}{|c|c|c|c|c|c|c|}
\hline & $M K T$ & $S M B$ & $H M L$ & & $U M O$ & Avg. $R^{2}$ \\
\hline (1) & $\begin{array}{c}-0.12 \\
(-0.28)\end{array}$ & & & & $\begin{array}{c}0.51 \\
(2.54)\end{array}$ & $30 \%$ \\
\hline (2) & $\begin{array}{c}-0.92 \\
(-3.25)\end{array}$ & $\begin{array}{c}0.16 \\
(0.94)\end{array}$ & $\begin{array}{c}0.35 \\
(1.95)\end{array}$ & & & $44 \%$ \\
\hline (3) & $\begin{array}{c}-0.57 \\
(-2.00)\end{array}$ & $\begin{array}{c}0.16 \\
(0.97)\end{array}$ & $\begin{array}{c}0.33 \\
(1.81)\end{array}$ & & $\begin{array}{c}0.75 \\
(4.83)\end{array}$ & $45 \%$ \\
\hline (4) & $\begin{array}{c}M K T \\
-0.62 \\
(-2.39)\end{array}$ & $\begin{array}{c}S M B \\
0.15 \\
(0.90)\end{array}$ & $\begin{array}{c}H M L \\
0.35 \\
(1.93)\end{array}$ & & $\begin{array}{c}U M O_{\perp \text { SEC }} \\
0.66 \\
(4.07)\end{array}$ & $\begin{array}{c}\text { Avg. } R^{2} \\
45 \%\end{array}$ \\
\hline (5) & $\begin{array}{c}M K T \\
-0.80 \\
(-2.52)\end{array}$ & $\begin{array}{c}S M B \\
0.16 \\
(0.98)\end{array}$ & $\begin{array}{c}H M L \\
0.35 \\
(1.95)\end{array}$ & $\begin{array}{r}M O M \\
0.00 \\
(0.01)\end{array}$ & $U M O$ & $\begin{array}{c}\text { Avg. } R^{2} \\
46 \%\end{array}$ \\
\hline (6) & $\begin{array}{c}-0.59 \\
(-1.90)\end{array}$ & $\begin{array}{c}0.18 \\
(1.07)\end{array}$ & $\begin{array}{c}0.34 \\
(1.85)\end{array}$ & $\begin{array}{c}-0.08 \\
(-0.25)\end{array}$ & $\begin{array}{c}0.73 \\
(4.46)\end{array}$ & $47 \%$ \\
\hline (7) & $\begin{array}{c}M K T \\
-0.87 \\
(-3.03)\end{array}$ & $\begin{array}{c}S M B \\
0.19 \\
(1.18)\end{array}$ & $\begin{array}{c}H M L \\
0.36 \\
(1.95)\end{array}$ & $\begin{array}{c}I N V \\
-0.12 \\
(-0.83)\end{array}$ & UMO & $\begin{array}{c}\text { Avg. } R^{2} \\
46 \%\end{array}$ \\
\hline (8) & $\begin{array}{c}-0.67 \\
(-2.44)\end{array}$ & $\begin{array}{c}0.19 \\
(1.16)\end{array}$ & $\begin{array}{c}0.33 \\
(1.83)\end{array}$ & $\begin{array}{l}-0.16 \\
(-1.13)\end{array}$ & $\begin{array}{c}0.74 \\
(4.60)\end{array}$ & $48 \%$ \\
\hline (9) & $\begin{array}{c}M K T \\
-1.05 \\
(-3.63)\end{array}$ & $\begin{array}{c}S M B \\
0.17 \\
(1.03)\end{array}$ & $\begin{array}{c}H M L \\
0.35 \\
(1.90)\end{array}$ & $\begin{array}{c}L E V \\
0.73 \\
(2.98)\end{array}$ & $U M O$ & $\begin{array}{c}\text { Avg. } R^{2} \\
46 \%\end{array}$ \\
\hline (10) & $\begin{array}{c}-0.71 \\
(-2.37)\end{array}$ & $\begin{array}{c}0.17 \\
(1.06)\end{array}$ & $\begin{array}{c}0.33 \\
(1.80)\end{array}$ & $\begin{array}{c}0.81 \\
(3.04)\end{array}$ & $\begin{array}{c}0.78 \\
(4.88)\end{array}$ & $46 \%$ \\
\hline
\end{tabular}

This table reports the Fama-MacBeth regression results using the 25 size and book-to-market portfolios from July 1972 through December 2008. The dependent variable is the value-weighted monthly excess returns (in percent) of the 25 portfolios. The independent variables are the loadings on a set of return factors, including $M K T, H M L, S M B, U M O, U M O_{\perp \mathrm{SEC}}, M O M, I N V$, and $L E V$, all defined in Table 2. The loadings of each portfolio on the factors are estimated from a time-series regression using monthly excess returns over the past 60 months as of the end of June of each year. The estimated loadings are used as independent variables in the cross-sectional regressions in each of the next 12 months from July of year $t$ through June of the year $t+1$. The time-series averages of the cross-sectional regression coefficients are reported. In parentheses are the associated robust Newey-West (1987) $t$-statistics. The avg. $R^{2} \mathrm{~s}$ are the time-series averages of the monthly adjusted $R$-squares across the full sample period.

premium, in which the $U M O$ loadings of the 25 portfolios are estimated within an annually updated rolling five-year window on the benchmark factors together with $U M O$. The mean premia and the Newey-West (1987) $t$-statistics are reported in Table 4.

Table 4 shows that the premium of $U M O$ is always positive, and economically and statistically significant for all model specifications. For instance, the average premium of $U M O$ in regression (1) is $0.51 \%$ per month $(t=2.54)$ controlling for the market factor, in (3) is $0.75 \%$ per month $(t=4.83)$ with controls for the three factors, and in regression (6) is $0.73 \%$ per month $(t=$ 4.46) with controls for the four factors. ${ }^{17}$ Similar results are obtained after

17 The coefficient on $U M O$ jumps when $S M B$ and $H M L$ are included in the regression, possibly owing to the omitted variable problem. If the true factor pricing model has the three factors plus $U M O$, then the coefficient estimate on $U M O$ can be downward biased when $S M B$ and $H M L$ are omitted. For example, Panel A of Figure 1 shows that large-value stocks have negative $U M O$ loadings and positive $H M L$ loadings. Adding HML loadings to the regression therefore increases the coefficient on $U M O$ by attributing the high returns of value stocks to high $H M L$ loadings instead of to low $U M O$ loadings. 
additionally controlling for $I N V$ and $L E V$, or replacing $U M O$ with $U M O_{\perp \mathrm{SEC}}$. The estimated $U M O$ premium ranges from $6.12 \%$ to $9.36 \%$.

Lewellen, Nagel, and Shanken (2010) show that a proposed factor that is correlated (even weakly) with $S M B$ and $H M L$ can spuriously price the 25 size$B M$ portfolios in the cross-section. To address this possibility, in Section 1 of the online Technical Appendix, we use the orthogonalized UMOs (which are orthogonalized to the three or four factors) to estimate $U M O$ loadings and then use these loadings in the Fama-MacBeth regressions. The results remain unchanged. Similar results also obtain for various sets of portfolios sorted based on size, book-to-market equity, external financing ( $E X F I N)$, and net composite issuance $(I R)$.

\subsection{UMO loadings and the cross-section of individual stock returns}

Behavioral theories imply that $U M O$ loadings should forecast the returns on individual stocks, as well as portfolios. Stocks with extreme sensitivity to $U M O$ should partake of greater systematic mispricing and have stronger return reversal when mispricing is corrected.

As discussed in Section 3.1, estimating $U M O$ loadings on individual stocks is challenging due to the (theoretically predicted) instability of these loadings. We therefore adopt two different approaches to estimate $U M O$ loadings.

\subsubsection{Conditional $U M O$ loadings estimated from daily returns over short} windows. Since misvaluation is temporary, we expect loadings to be unstable over long horizons. So, in the first approach, we estimate UMO loadings from daily returns over a short period, an approach also used in previous studies (e.g., Lewellen and Nagel 2006), and then test for stability. We estimate firm-level UMO loadings using at least 100 daily returns over the most recent 12-month period with controls for the three factors. We call the estimated $U M O$ loading the pre-formation loading, denoted as $\beta_{u}^{\text {pre }}$. (Reducing the estimation period to three months yields similar results.)

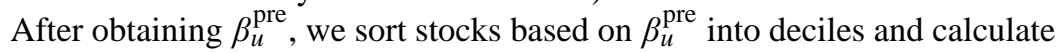
both the equal-weighted decile returns in the following month. As shown in Table 5, the post-ranking $U M O$ loadings, $\beta_{u}^{\text {post }}$, increase almost monotonically with the pre-ranking loading ranks, suggesting that $U M O$ loadings are persistent over a 12-13-month period. Decile returns tend to increase with $\beta_{u}^{\text {pre }}$, with return differentials between the highest and the lowest $\beta_{u}^{\text {pre }}$ deciles of $0.77 \%$ per month $(t=3.75)$, or $9.24 \%$ per annum. The alphas from the CAPM and the three-factor model remain sizable and statistically significant, with mean annual abnormal returns of 7.6-10.8\%. Table 5 also shows that after excluding firms in $U M O$, the effect remains strong (with a slight reduction in the size of the long-short returns). Overall, the results show an economically and statistically significant premium on $U M O$ at the firm level, even among those firms that are not recently involved in external issuances or repurchases. 
Table 5

Return performance of deciles based on $U M O$ loadings estimated from past 12-month daily returns

\begin{tabular}{|c|c|c|c|c|c|c|}
\hline \multirow[b]{2}{*}{$\beta_{u}^{\text {pre }}$ Rank } & \multicolumn{3}{|c|}{ All sample firms } & \multicolumn{3}{|c|}{ Excl. UMO firms } \\
\hline & $R E T$ & $\beta_{u}^{\text {pre }}$ & $\beta_{u}^{\text {post }}$ & $R E T$ & $\beta_{u}^{\text {pre }}$ & $\beta_{u}^{\text {post }}$ \\
\hline $\mathrm{L}$ & 0.82 & -2.16 & -0.99 & 0.84 & -2.18 & -0.88 \\
\hline 2 & 1.11 & -0.98 & -0.56 & 1.01 & -1.00 & -0.58 \\
\hline 3 & 1.26 & -0.57 & -0.35 & 1.16 & -0.59 & -0.41 \\
\hline 4 & 1.21 & -0.31 & -0.25 & 1.09 & -0.33 & -0.36 \\
\hline 5 & 1.28 & -0.11 & -0.10 & 1.25 & -0.12 & -0.18 \\
\hline 6 & 1.28 & 0.08 & -0.06 & 1.17 & 0.06 & -0.07 \\
\hline 7 & 1.22 & 0.27 & -0.02 & 1.15 & 0.25 & -0.09 \\
\hline 8 & 1.35 & 0.50 & 0.03 & 1.26 & 0.48 & -0.06 \\
\hline 9 & 1.23 & 0.85 & 0.04 & 1.15 & 0.82 & 0.02 \\
\hline $\mathrm{H}$ & 1.58 & 2.00 & 0.01 & 1.46 & 1.91 & -0.15 \\
\hline $\mathrm{H}-\mathrm{L}$ & 0.77 & 4.16 & 0.99 & 0.62 & & 0.73 \\
\hline$t(\mathrm{H}-\mathrm{L})$ & $(3.75)$ & & $(9.23)$ & $(3.15)$ & & (10.17) \\
\hline$\alpha_{\mathrm{CAPM}}$ & 0.90 & & & 0.73 & & \\
\hline$t\left(\alpha_{\mathrm{CAPM}}\right)$ & $(4.67)$ & & & $(3.95)$ & & \\
\hline$\alpha_{\mathrm{FF} 3}$ & 0.63 & & & 0.54 & & \\
\hline$t\left(\alpha_{\mathrm{FF} 3}\right)$ & $(3.82)$ & & & $(3.27)$ & & \\
\hline
\end{tabular}

This table reports the average monthly percentage decile returns sorted based on pre-formation conditional $U M O$ loadings, $\beta_{u}^{\text {pre }}$, from July 1973 through December 2008. The sorting variable $\beta_{u}^{\text {pre }}$, for each stock, is the coefficient $\beta_{u}$ in the following regression, which requires at least 100 daily stock returns from month $t-12$ through $t-1$ :

$$
R-r_{f}=\alpha+\beta_{m} M K T+\beta_{S} S M B+\beta_{h} H M L+\beta_{u} U M O+\epsilon .
$$

At the end of month $t-1$, stocks are sorted based on $\beta_{u}^{\text {pre }}$ into deciles and the equal-weighted decile returns of month $t$ are reported. The portfolio $\mathrm{H}-\mathrm{L}$ is long on the highest $\beta_{u}^{\mathrm{pre}}$ decile and short on the lowest $\beta_{u}^{\mathrm{pre}}$ decile. The variable $\alpha_{\mathrm{CAPM}}$ is the intercept from the regression of the full sample monthly $\mathrm{H}-\mathrm{L}$ returns on $M K T$. The variable $\alpha_{\mathrm{FF} 3}$ is the intercept from a similar regression with controls for the Fama-French three factors. The reported pre-formation $U M O$ loading $\left(\beta_{u}^{\text {pre }}\right)$ is averaged across stocks included in each decile and then averaged across months. The post-formation $U M O$ loading $\beta_{u}^{\text {post }}$ is estimated using the full-sample monthly decile returns from the above regression. Columns 2-4 use all firms, and the last three columns exclude firms in $U M O$ of the current year. Robust Newey-West (1987) $t$-statistics are reported in parentheses.

\subsubsection{Conditional $U M O$ loadings estimated from characteristics portfo-}

lios. The first approach to estimating $U M O$ loadings has the advantage of providing firm-level loadings. This method, however, is known to generate relatively imprecise loadings since firm-level loadings tend to be more subject to regression to the mean.

To obtain more precise $U M O$ loadings, we now employ a modified version of the estimation procedure by Fama and French (1992), known as the portfolio shrinkage method. However, instead of estimating unconditional $U M O$ loadings using past three- to five-year firm-level returns as in Fama and French (1992), we estimate conditional security $U M O$ loadings from annually balanced portfolios sorted by mispricing proxies. Again, this is because mispricing tends to be temporary and reverses out during a period of three to five years.

In this procedure, at the end of each month from June of year $t$ through May of year $t+1$, we first sort all stocks into 100 portfolios according to two characteristics that proxy for misvaluation, such as firm size $(M E)$ during 
the most recent June and the external financing variable $(E X F I N)$ calculated at the fiscal year ending as of December of year $t-1$. By sorting stocks based on mispricing proxies, we create dispersion in the sensitivities to $U M O$. We then estimate the $U M O$ loadings for each of the 100 equal-weighted portfolios using at least 36-month returns, from July 1972 through month $t-1$, in a timeseries regression that controls for the four factors. ${ }^{18}$ Each individual stock then assumes the loading of the portfolio it belongs to in month $t-1 .^{19}$

We denote the conditional $U M O$ loadings as $\beta^{\mathrm{UMO}}$ and use these loadings to forecast stock returns in month $t$ with controls for a set of standard predictors, which include logarithmic firm size, $\operatorname{LOG}(M E)$, logarithmic book-to-market, LOG $(B M)$, past one-month return, $r_{(t-1)}$, past returns from month $t-12$ to $t-2, r_{(t-12, t-2)}$, past returns from month $t-36$ to $t-13, r_{(t-36, t-13)}$, industry dummies based on the Fama-French 49 industry classifications, and the three-factor loadings. ${ }^{20}$ The past return measures are expressed on a monthly basis. UMO loadings are normalized and standardized to have zero mean and unit variance. The estimated coefficients are averaged across time and reported in Table 6. Prediction 3 implies a positive average coefficient on the UMO loading, indicating that a higher $U M O$ loading tends to increase a stock's return holding constant the controls.

Consistent with Prediction 3, Specifications (1) and (2) in Panel A of Table 6 show that the average coefficients of $\beta^{\mathrm{UMO}}$ are all positive and statistically significant, before and after adding the standard controls. Before controlling for the standard return predictors, the coefficient of $\beta^{\mathrm{UMO}}$ is 0.48 $(t=6.87)$; after, the coefficient of $\beta^{\mathrm{UMO}}$ is $0.36(t=8.71)$. This implies that a move from the lowest (mean $\beta^{\mathrm{UMO}}$ of -1.78 ) to the highest (mean $\beta^{\mathrm{UMO}}$ of 1.78) decile incrementally increases annual abnormal return by $15.42 \%$ $(=(1.78-(-1.78)) \times 0.36 \% \times 12)$. After excluding as observations those stocks used to form $U M O$ of the current year, in Panel B the coefficient with controls implies a marginal effect moving from the lowest to the highest $\beta$ UMO decile of $14.21 \%$ per annum. Overall, this evidence shows that stocks that load heavily on $U M O$ on average earn higher returns, even after controlling for standard return predictors, and even when we eliminate firms that have recently engaged in new issues or repurchases.

Next, we run a horse race between $U M O$ loadings and a set of other return predictors documented in recent literature, including external financing (EXFIN) as in Bradshaw, Richardson, and Sloan (2006), net composite

18 Using a rolling window over the past 60 months to estimate $U M O$ loadings produces qualitatively similar results.

19 The results are similar if combinations of size, book-to-market, external financing (EXFIN), or net equity issuance $(I R)$ are used to sort the characteristic portfolios. We expect to obtain appropriate estimates of $U M O$ loadings as long as the characteristic variables are sufficiently good proxies for stock mispricing to create substantial dispersion in $U M O$ loadings.

20 The predictors are designed to capture the size effect, the book-to-market effect, the short-term return contrarian effect, the momentum effect, the long-term reversal effect, the industry effects, and systematic risks. 


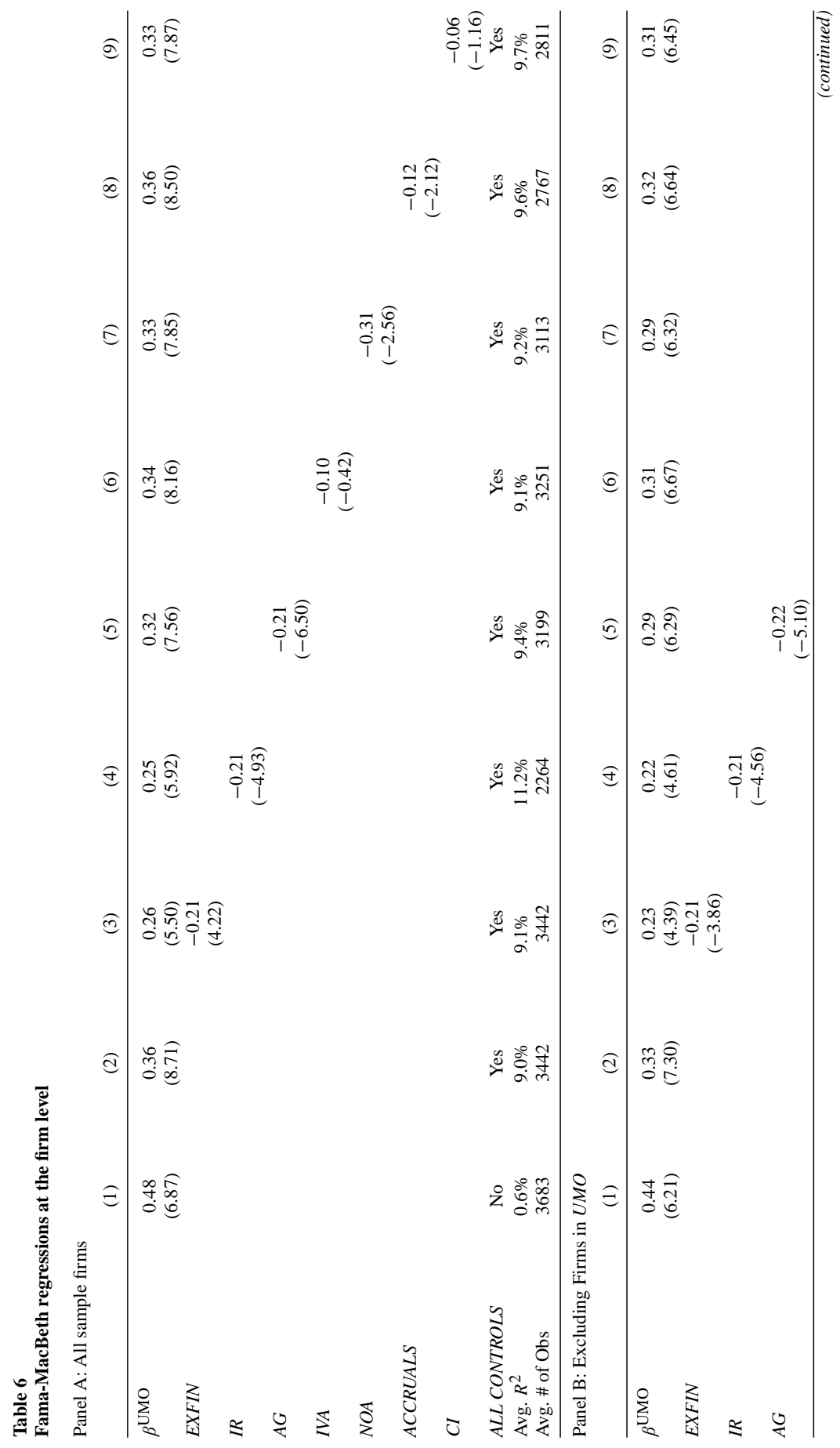




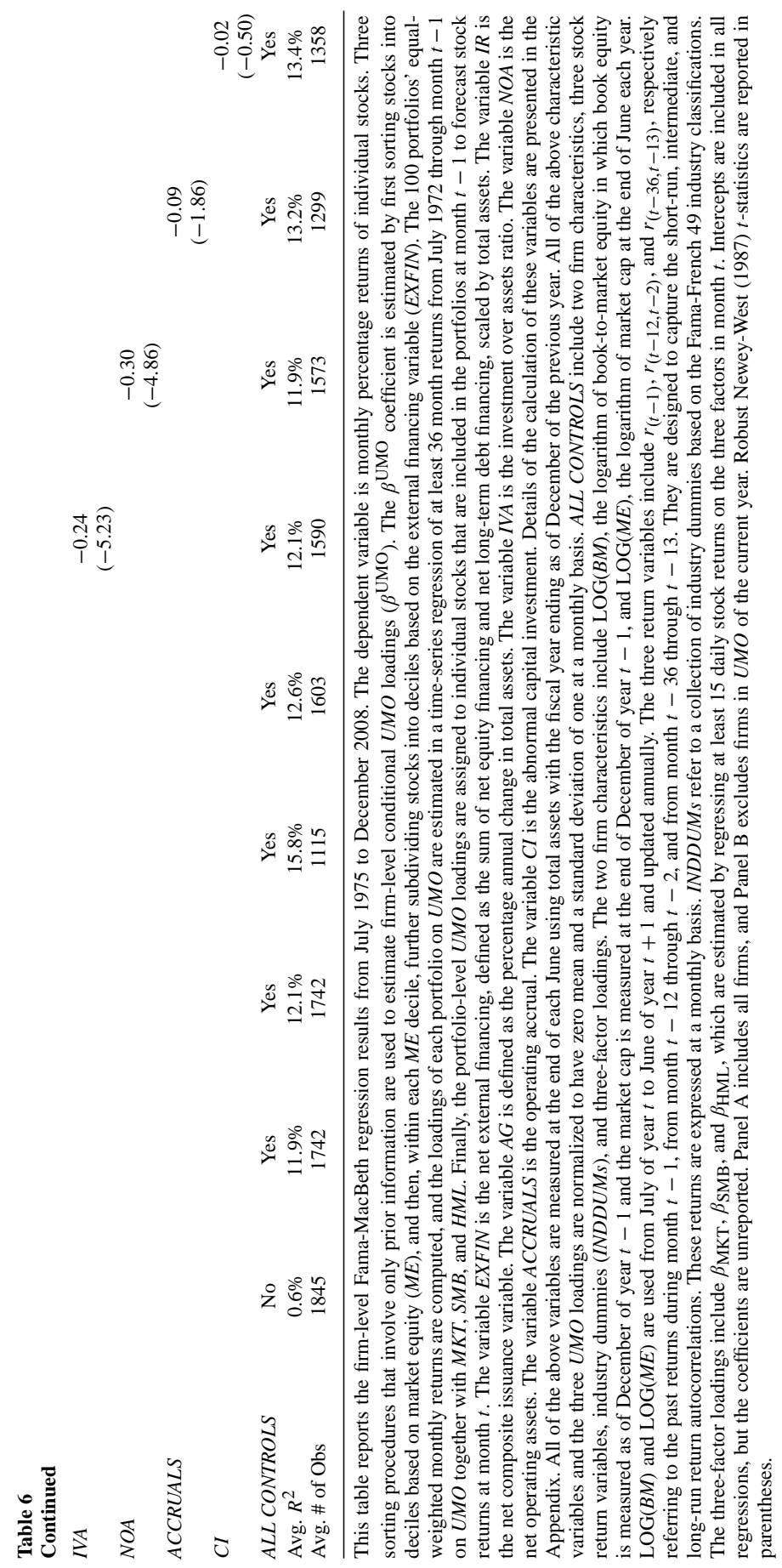


issuance (IR) as in Daniel and Titman (2006), the asset growth variable $(A G)$ as in Cooper, Gulen, and Schill (2008), the investment-asset ratio (IVA) as in Lyandres, Sun, and Zhang (2008), net operating assets (NOA) as in Hirshleifer, Hou, Teoh, and Zhang (2004), operating accruals (ACCRUALS) as in Teoh, Welch, and Wong (1998a, 1998b), and the abnormal capital investment $(C I)$ of Titman, Wei, and Xie (2004). One purpose is to see whether $U M O$ loadings have an ability to predict the cross-section of returns incremental to known predictors. Furthermore, some or all of these characteristics have been interpreted as proxies for firm-level mispricing. On theoretical grounds, in a behavioral setting we expect $U M O$ loadings, as proxies for systematic underpricing, can have incremental return predictability beyond that of firm characteristics. $^{21}$

In Table 6, from regressions (3)-(9), we run the Fama-MacBeth regressions on $U M O$ loadings, the set of standard controls, and each of the seven new return predictors. As with the UMO loadings, these new predictors are normalized and standardized to have zero mean and unit variance for each month. The results confirm the ability of $U M O$ loadings to positively forecast returns after controlling for these additional predictors. The coefficients on the normalized $U M O$ loadings range from 0.25 to 0.36 , indicating a marginal effect on returns of $10.76 \%$ to $15.44 \%$. The coefficients on the seven other predictors (from -0.06 to -0.31 ) all imply a smaller marginal effect. For example, the net issuance variable $I R$ has the largest marginal effect among these predictors. Moving from the highest to the lowest $I R$ decile, the coefficient -0.21 implies an increase in decile returns by $8.67 \%$, which is considerably smaller than that of $U M O$ loadings. ${ }^{22}$ In unreported analyses, we also find that when we run a horse race between $U M O$ loadings and the seven other predictors (together with the set of standard controls), UMO loadings remain positive and significant.

In Panel B, we run Fama-MacBeth regressions excluding as observations those stocks used to form $U M O$ of the current year. Again, we find that $U M O$ loadings have significant power to forecast the cross-section of stock returns incremental to known return predictors. The finding that both $U M O$ loadings and firm characteristics contain distinct incremental power to forecast returns is consistent with the hypothesis that $U M O$ loadings contain information about

21 Daniel, Hirshleifer, and Subrahmanyam (2005) describe a behavioral model with no risk premia, wherein both factor and firm-specific cash flow components can be mispriced. If so, characteristics are proxies for both factor mispricing and the mispricing of firm-specific (idiosyncratic) cash flow components; loadings on a pricecharacteristic-based factor portfolio (such as $H M L$ ) are proxies for factor mispricing. In a cross-sectional regression of returns on both characteristics and covariances, the coefficient on the characteristic implicitly forces the coefficients on the factor mispricing and the idiosyncratic mispricing to be the same. When factor mispricing is stronger than firm-specific mispricing, loadings pick up the difference and therefore are positive incremental return predictors. Daniel, Hirshleifer, and Subrahmanyam (2005) consider characteristics and characteristicsbased factors formed on the basis of market price rather than on the basis of managerial actions such as issuance and repurchase, but a similar intuition applies.

22 In Panel A, the variables IVA and $C I$ are statistically significant as return predictors when $U M O$ loadings are excluded, but not when $U M O$ loadings are included. So, $U M O$ loadings subsume the predictive power of these variables. 
firms' systematic mispricing and that the characteristics contain information about firm-specific mispricing, as compared with the rational factor pricing prediction that only covariances matter.

An alternative explanation for the finding that $U M O$ loadings strongly predict returns but that the characteristics also incrementally predict returns is that markets are efficient, the loadings on an underlying new issue/repurchase factor are priced, but $U M O$ is a poor proxy for that factor. However, if so, then the unobserved risk factor must have a large risk premium to explain both the high Sharpe ratio of $U M O$ and the incremental ability of the characteristic to predict returns. As discussed earlier, the Sharpe ratio of $U M O$ is about $21 / 2$ times as large as that of the market portfolio, and is considerably higher than that of $H M L$.

The high Sharpe ratio of the market (the equity premium puzzle) is already viewed as a challenge to rational asset pricing; Mackinlay (1995) describes the Sharpe ratio achievable with the Fama-French factors as a further challenge. $U M O$ sharpens the challenge in two ways. First, its Sharpe ratio exceeds those of the Fama-French and momentum factors. Second, the incremental power of the characteristics to predict returns implies that an even higher Sharpe ratio than that of $U M O$ can potentially be achieved by combining $U M O$ with financing variable-based portfolios.

A different possibility is that $U M O$ is the correct risk factor, but that loadings are estimated with noise, causing them to predict returns imperfectly. Such noise can derive from limited sample size or from time variation in loadings. If so, characteristics may incrementally predict returns because they are proxies for true $U M O$ loadings. However, the same objection applies to this explanation: that the Sharpe ratios that are in principle achievable using $U M O$ and the characteristics are surprisingly high.

Section 2 and Table 3 of the online Technical Appendix provide evidence suggesting that stocks with extreme $U M O$ loadings tend to be hard to value or to arbitrage. This may help explain why the mispricing associated with extreme $U M O$ loadings can persist.

\section{Are $U M O$ Loadings Stable?}

Finally, we examine whether UMO loadings are fairly stable over periods of three to five years. The presumption for a pure mispricing factor is that the loadings are unstable over the typical frequency at which mispricing appears and corrects, i.e., as a stock shifts between being over- versus underpriced. In contrast, for a rational priced factor there is no presumption that loadings will be unstable. A common presumption for tests of rational asset pricing has been that loadings are stable for periods of three to five years.

To estimate the systematic risk of stocks, it is a common practice to estimate loadings on a fundamental risk factor (such as the market) by sorting stocks based on pre-ranking loadings that are estimated from the previous 
three to five years (Fama and MacBeth 1973; Ferson and Harvey 1991; Fama and French 1992). The presumption underlying this practice is that firm fundamentals evolve gradually, so that a firm's sensitivity to cash flow factors usually does not change dramatically during a relatively short period of time.

Under the hypothesis that securities have fairly stable loadings on fundamental economic risks, pre-ranking loadings should be highly positively correlated with post-ranking loadings. Thus, sorting firms by pre-ranking loadings should create a large dispersion in post-ranking loadings. In contrast, if $U M O$ loadings reflect mispricing, they are likely to be unstable over periods as long as five years. Therefore pre-ranking loadings should be very poor proxies for misvaluation, and should have little power to predict post-ranking loadings. Additionally, sorting firms based on pre-ranking loadings should create little dispersion in post-ranking loadings.

Following Fama and French (1992), we estimate UMO pre-ranking loadings $\left(b_{\mathrm{pre}}^{\mathrm{UMO}}\right)$ by regressing individual stock monthly returns from the previous 36 to 60 months on $U M O$ together with the Fama-French three factors, and sort stocks into 100 portfolios based on their $b_{\mathrm{pre}}^{\mathrm{UMO}}$. Using the full-sample equal-weighted returns of the 100 portfolios, we estimate the post-ranking $U M O$ loadings ( $b_{\text {post }}^{\mathrm{UMO}}$ ) in a multi-factor regression for each portfolio. We report the average $b_{\text {pre }}^{\mathrm{UMO}}$ and the estimated $b_{\text {post }}^{\mathrm{UMO}}$ for the 100 portfolios in Table 7.

Our preliminary analyses show that the average loadings on MKT and SMB are positive while those on $H M L$ and $U M O$ are close to zero. To facilitate the comparison across different factors, we subtract the means from the pre- and post-ranking loadings. For pre-ranking loadings, the monthly mean loadings are used. Since the loadings are demeaned, we expect a reasonable number of portfolios with moderate loadings to flip signs simply due to the changes in the means (or simply random errors in estimation). Thus, we focus on the 20 extreme-loadings portfolios, which include the top and the bottom 10. If firms have reasonably persistent sensitivity to $U M O$ as a stable risk factor, we expect $U M O$ loadings to retain their signs and pre-ranking beta ranks during the post-formation period. In contrast, if $U M O$ is a mispricing factor, even the extreme loadings can change rapidly and can often flip signs.

Panel A of Table 7 reports the average demeaned pre-ranking loadings of the 100 UMO loading portfolios. Panel $\mathrm{B}$ reports the demeaned post-ranking portfolio loadings. We focus on the 20 extreme loading portfolios (either positive or negative) for the reasons stated above. Contrary to the hypothesis that factor loadings are persistent for long periods, 10 out of the 20 extreme portfolios switch the signs of their $b_{\mathrm{pre}}^{\mathrm{UMO}} \mathrm{s}$ in the subsequent one year, shown in Panel B and summarized in Panel C. Instability of loadings is not driven solely by new issues or repurchase stocks; after excluding the firms in $U M O$, we still observe 10 out of the 20 extreme portfolios switching signs from pre-ranking to post-ranking periods. 


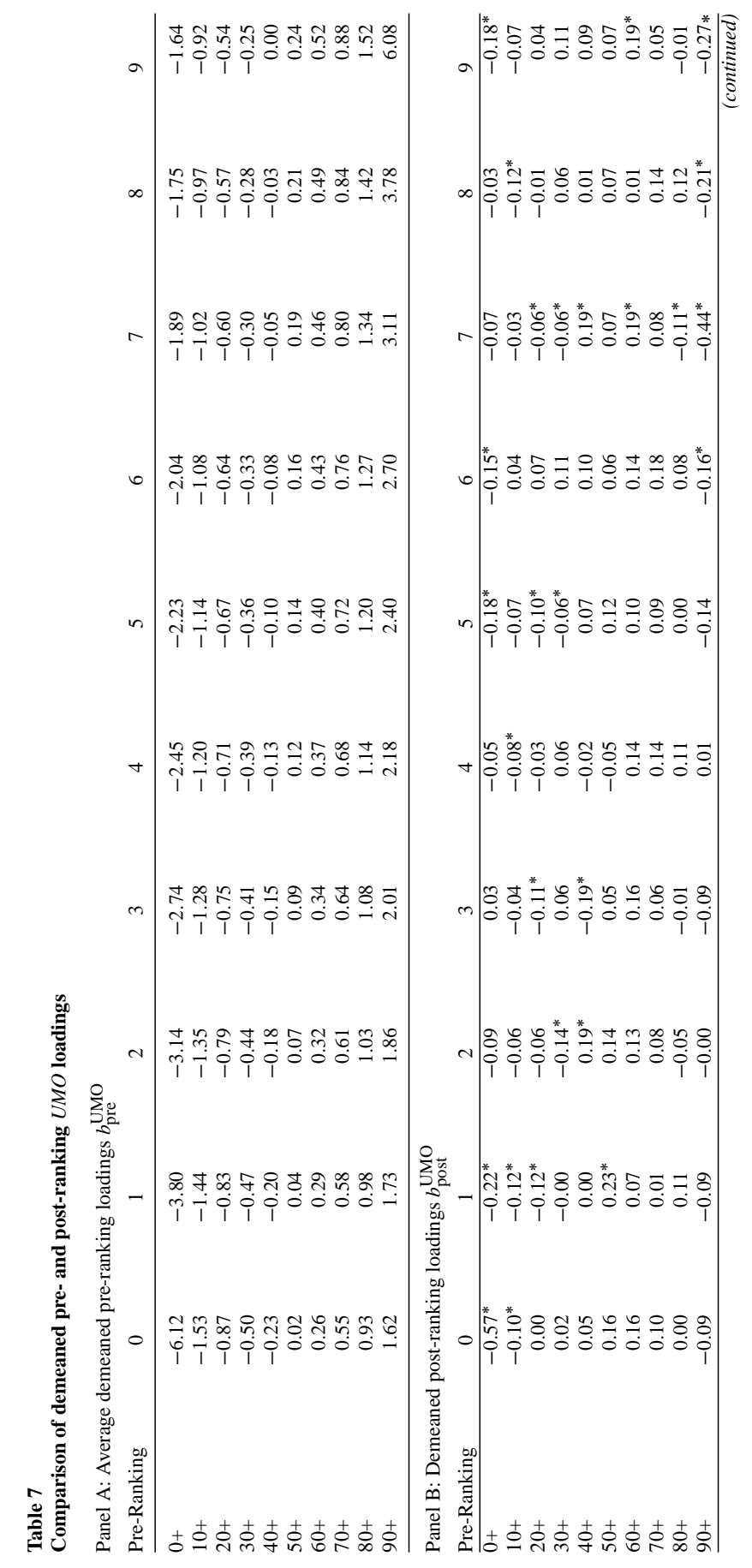




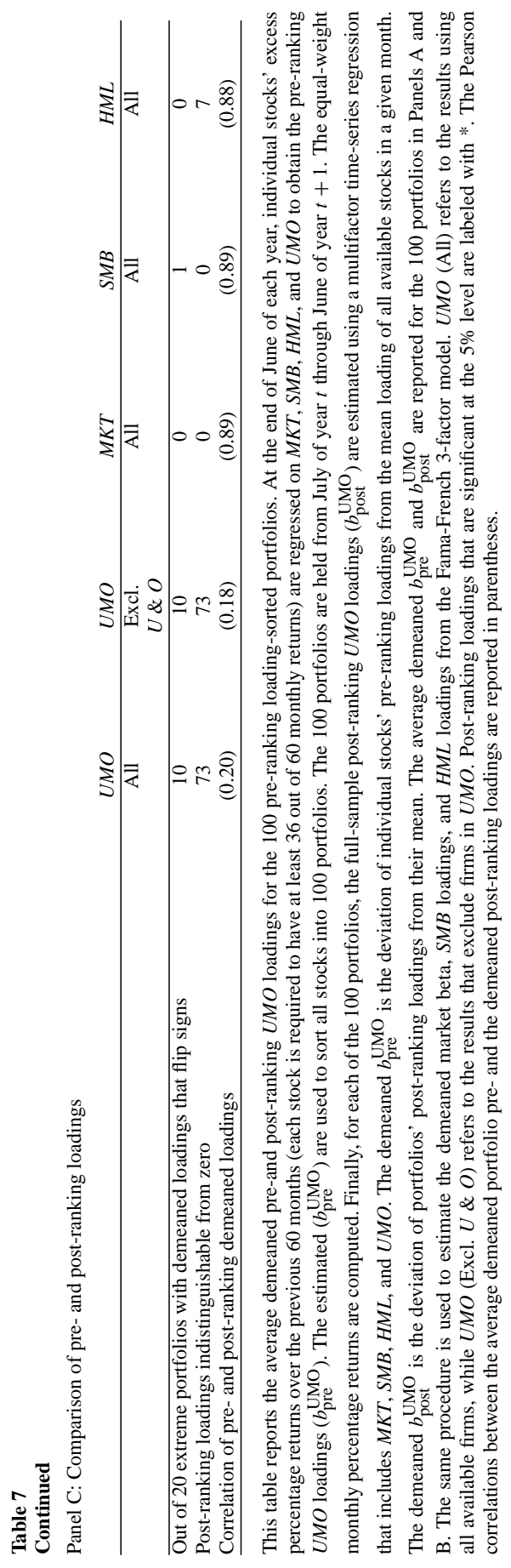


These numbers are substantially greater than those associated with $M K T$, $S M B$, and $H M L$ when we use the same method to estimate market beta and loadings on $S M B$ and $H M L$. As reported in Panel $\mathrm{C}$, there are no $M K T$ and $H M L$ loading portfolios and only one $S M B$ loading portfolio among the extreme 20 that have opposite comovement with their corresponding factor before and after the portfolio formation. The inferences remain similar if we use raw, rather than demeaned, loadings.

Overall, a strong majority, 73 out of 100 UMO loading portfolios, have essentially zero post-ranking loadings, suggesting that sorting stocks based on $b_{\mathrm{pre}}^{\mathrm{UMO} / \mathrm{s}}$ creates little dispersion in $b_{\text {post }}^{\mathrm{UMO}} \mathrm{s}$. (Results are similar if we exclude firms in $U M O$ from our analyses of loadings.) In contrast, by applying the same method to $M K T, S M B$, and $H M L$, we find that none of the market beta and $S M B$ loading portfolios, and only seven $H M L$ loading portfolios, carry post-ranking loadings that are insignificantly different from zero. ${ }^{23}$ These patterns are also evidenced in Figure 5, which plots the pre- and post-ranking loadings associated with $U M O$ and the three factors.

The time-series average of the cross-sectional correlations between pre- and post-ranking loadings again indicates that $U M O$ loadings are much less persistent than those on $M K T, S M B$, and $H M L$. This correlation is between 0.88 to 0.89 for the three factors but merely 0.20 for $U M O$ for general firms and 0.18 after excluding firms in $U M O .^{24}$ The substantially lower correlation in pre- and post-ranking $U M O$ loadings is consistent with our findings that $U M O$ loadings tend to flip signs and are unstable over periods of several years.

Taken together, this evidence suggests that $U M O$ loadings shift too rapidly to be captured by long-window estimates. If firms' fundamental exposure to systematic risk tends to be fairly persistent and to evolve gradually, we would expect a better measure of mispricing to be less persistent. The sensitivities of stock returns to $U M O$ are indeed much less persistent than the loadings on proposed fundamental risk factors reported in previous literature.

\section{Conclusion}

Behavioral approaches to asset pricing imply that there is common misvaluation across firms, and that there is systematic comovement associated with firms that are similarly misvalued. This study documents that, over the period 1972-2008, returns on issuing and repurchasing firms can be used to identify commonality in returns, and provides evidence suggesting that this return commonality derives from commonality in misvaluation.

23 It is possible that more pre-ranking $U M O$ loadings are closer to zero than are the pre-ranking $M K T, S M B$, or $H M L$ loadings. If so, this would only reinforce the point that loadings on $U M O$ are not stable over periods as long as five years.

24 The greater the extent to which loadings capture persistent fundamental risks rather than mispriced factors, the more stable we expect these loadings to be. So, the relative instability of $U M O$ loadings suggests that $U M O$ is a purer proxy for misvaluation than the Fama-French factors. 

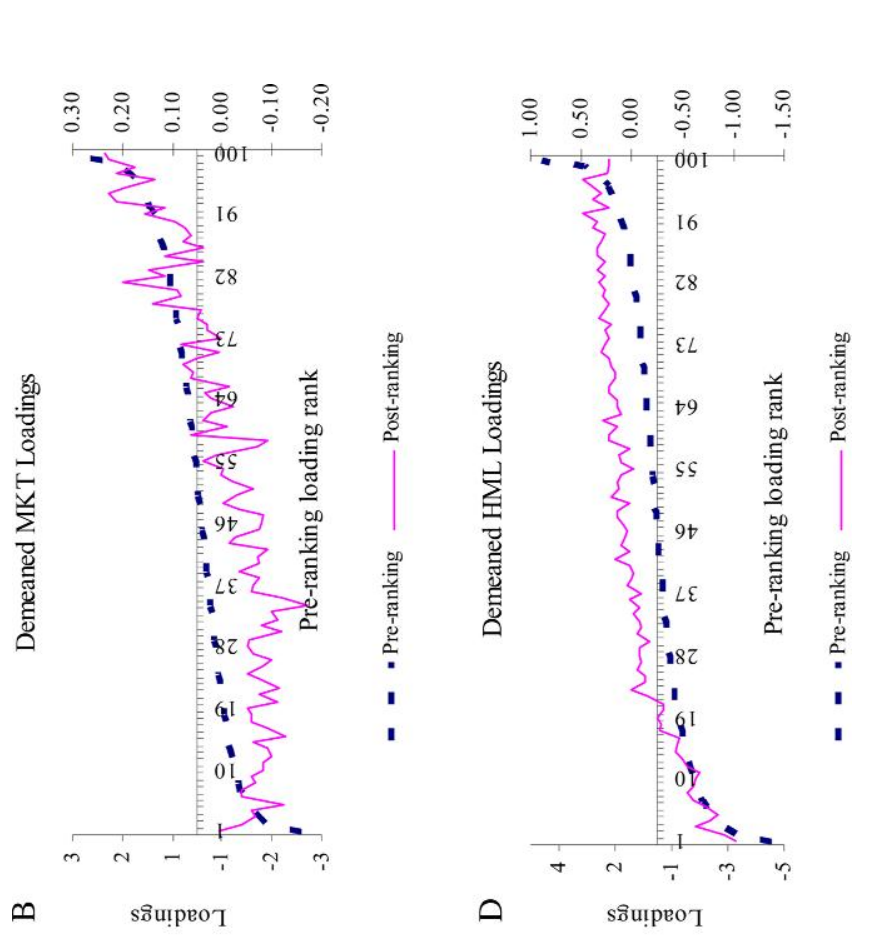

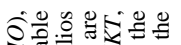

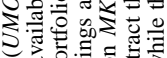

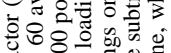

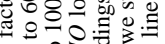

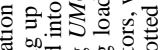

.

至

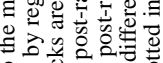

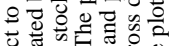

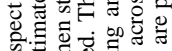

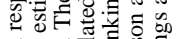

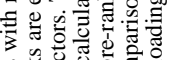

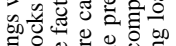

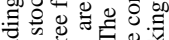

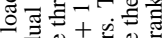

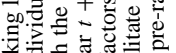

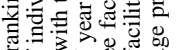

넝

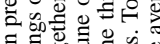

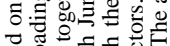

舟응

O

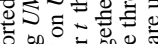

on

政

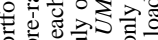

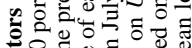

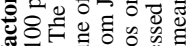

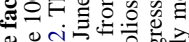
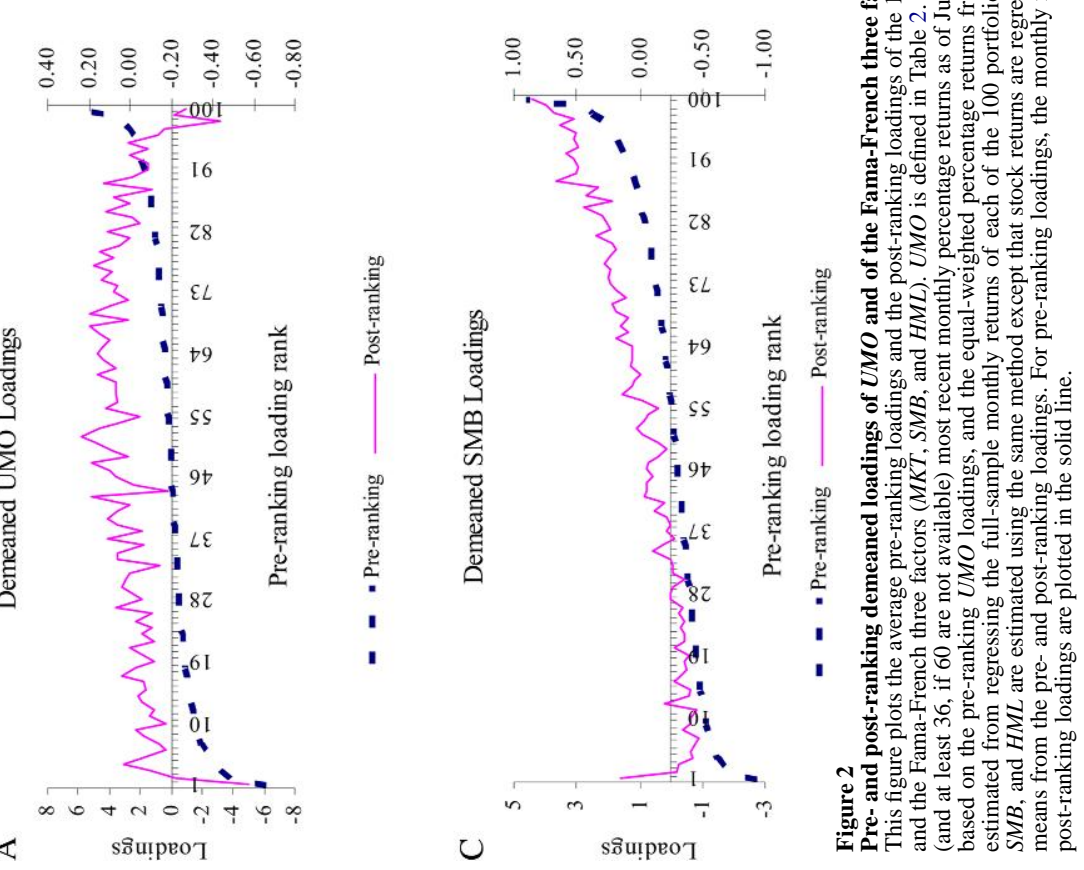
Existing research has proposed that firms undertake equity issues in response to overpricing and repurchases in response to underpricing. These financing events seem to reflect the stock mispricing perceived by managers that is not fully captured by firm characteristics such as book-to-market equity. Building upon this literature, our evidence indicates that there is comovement in returns associated with financing events, and that firms that engage in similar events subsequently move together more. However, this comovement is not unique to firms that are involved with these transactions-it is shared by general firms that load upon our misvaluation factor.

Probably the most surprising results here are the exceptionally high Sharpe ratio of $U M O$ and the strong ability of $U M O$ loadings to predict the crosssection of stock returns. When $U M O$ competes with the Fama-French three factors, the momentum factor, and the leverage factor, the ex post tangency portfolio places a much higher weight on $U M O$ than on the other factors. When we regress $U M O$ on the set of benchmark factors, $U M O$ produces consistently positive alphas and large residual variance. This evidence confirms that, despite some critiques of the new issue and repurchase puzzles in the literature (e.g., Brav, Geczy, and Gompers 2000; Butler, Grullon, and Weston 2005), new issue and repurchase events do indeed contain important information for predicting returns. Moreover, the UMO loading is a strong predictor of the cross-sectional stock returns, with a marginal effect that is considerably greater than those of the other firm characteristics that we consider. The strong and distinct ability of UMO loadings to forecast the cross-section of portfolio and stock returns suggests that firms' external financing activities convey information about the systematic component of stock misvaluation.

Although it is hard to rule out frictionless rational factor pricing explanations for return predictability conclusively, taken together, we view this evidence as more supportive of commonality in misvaluation that can be identified by means of financing events. However, we do not try to test explanations (not necessarily mutually exclusive) based upon market frictions such as illiquidity that may make it harder to realize the high Sharpe ratios associated with financing-based portfolios.

\section{Supplementary Data}

Supplementary data are available online at http://rfs.oxfordjournals.org.

\footnotetext{
Appendix

Book-to-market equity (BM): Following Polk and Sapienza (2009), we define $B E$ as stockholders' equity, plus balance sheet deferred taxes $(T X D B)$ and investment tax credit (ITCB, set to zero if unavailable), plus postretirement benefit liabilities (PRBA), minus the book value of preference stocks. Depending on availability, in order of preference, we use redemption (PSTKRV), liquidation $(P S T K L)$, or carrying value $(P S T K)$. Stockholders' equity is measured as the book value of common equity $(S E Q)$, plus the book value of preferred stock. If common equity is not available, we use the book value of assets $(A T)$ minus total liabilities $(L T)$. To compute $B M$, we match $B E$
} 
for all fiscal year-ends in calendar year $t-1$ with the firm's market equity at the end of December of year $t-1$.

Investment/asset ratio (IVA): Following Lyandres, Sun, and Zhang (2008), we measure investment-to-assets as the annual change in gross property, plant, and equipment (PPEGT) plus the annual change in inventories (INVT) divided by the lagged book value of assets $(A T)$. We perform a triple sort on size, book-to-market, and investment-to-assets based on the breakpoint of the top $30 \%$ and the bottom $30 \%$ into 27 portfolios. We define the investment factor $(I N V)$ as the average value-weighted returns of the nine low investment-to-assets portfolios minus the average returns of the nine high investment-to-assets portfolios.

Leverage ( $\boldsymbol{L E V})$ : Following Ferguson and Shockley (2003), we measure leverage $(B D / M E)$ as the book value of total liabilities $(L T)$ over the market value of equity. We match $L T$ for all fiscal year-ends in calendar year $t-1$ with the firm's market equity at the end of December of year $t-1$. We perform a triple sort on size, book-to-market, and $B D / M E$ based on the breakpoint of the top $30 \%$ and the bottom $30 \%$ to form 27 portfolios. We define the leverage factor as the average value-weighted returns of the nine high-leverage portfolios minus the average returns of the nine low-leverage portfolios.

External financing (EXFIN): Following Bradshaw, Richardson, and Sloan (2006), external financing $(E X F I N)$ is defined as the net amount of cash flow received from external financing activities, including net equity and debt financing, scaled by total assets $(A T)$. Net equity financing is defined as the sale of common and preferred stock (SSTK) minus the purchase of common and preferred stock (PRSTKC) minus cash dividends paid $(D V)$. Net debt financing is defined as the issuance of long-term debt (DLTIS) minus the reduction in long-term debt (DLTR). Unlike Bradshaw, Richardson, and Sloan (2006), we do not include change in current debt in calculating net debt financing to avoid including natural retirement of short-term debt (which is not a market timing choice) as opposed to debt repurchases.

The net composite issuance variable (IR): Following Daniel and Titman (2006), IR is defined as

$$
I R_{t-1}=\log \left(\frac{M E_{t-1}}{M E_{t-60}}\right)-r(t-60, t-1),
$$

where $M E$ is the market equity with the subscripts referring to the month and $r(t-60, t-1)$ is the stock return in the previous 60 months from month $t-60$ through $t-1$, adjusted for stock splits and stock dividends. $I R$ captures the part of the growth of the market value that is not attributed to stock returns, which is due instead to new issue, repurchase, and other activities that affect market value.

Net operating assets (NOA): Following Hirshleifer, Hou, Teoh, and Zhang (2004), net operating assets are defined as the difference of operating assets minus operating liabilities over total assets. Operating assets are total assets $(A T)$ minus cash and short-term investment $(C H E)$. Operating liabilities are total assets $(A T)$ minus the sum of short-term debt $(D L C)$, long-term debt (DLTT), minority interest $(M I B)$, preferred stock ( $P S T K)$, and common equity $(C E Q)$, deflated by the lagged total assets $(A T)$.

Operating accruals (ACC): Following Hirshleifer, Hou, Teoh, and Zhang (2004), operating accruals are defined as changes in current assets $(A C T)$ minus changes in cash $(\mathrm{CH})$, changes in current liabilities $(L C T)$ plus the sum of changes in short-term debt $(D L C)$ and changes in taxes payable $(T X P)$, and minus depreciation and amortization expense $(D P)$, deflated by the lagged total assets $(A T)$.

Abnormal capital investment (CI): Following Titman, Wei, and Xie (2004), the abnormal capital investment $(C I)$ is defined as a firm's capital expenditures $(C A P X)$ scaled by the moving-average of its capital expenditures over the previous three years. 


\section{References}

Baker, M., and J. Wurgler. 2000. The Equity Share in New Issues and Aggregate Stock Returns. Journal of Finance 55:2219-57.

- 2002. Market Timing and Capital Structure. Journal of Finance 57:1-32.

2006. Investor Sentiment and the Cross-Section of Stock Returns. Journal of Finance 61:1645-80.

2007. Investor Sentiment in the Stock Market. Journal of Economic Perspectives 21:129-51.

Baker, M., J. C. Stein, and J. Wurgler. 2003. When Does the Market Matter? Stock Prices and the Investment of Equity-Dependent Firms. Quarterly Journal of Economics 118:969-1005.

Barber, B. M., T. Odean, and N. Zhu. 2009. Systematic Noise. Journal of Financial Markets 12:547-69.

Barberis, N., M. Huang, and J. Santos. 2001. Prospect Theory and Asset Prices. Quarterly Journal of Economics 141:1-53.

Barberis, N., and A. Shleifer. 2003. Style Investing. Journal of Financial Economics 68:161-99.

Barberis, N., A. Shleifer, and J. Wurgler. 2005. Comovement. Journal of Financial Economics 75:283-317.

Berk, J., R. C. Green, and V. Naik. 1999. Optimal Investment, Growth Options, and Security Returns. Journal of Finance 54:1553-607.

Boehme, R., and S. Sorescu. 2002. The Long-Run Performance Following Dividend Initiations and Resumptions: Underreaction or Product of Chance? Journal of Finance 57:871-900.

Boyer, B. H. 2010. Forthcoming. Style-Related Comovement: Fundamentals or Labels?. Journal of Finance.

Bradshaw, M. T., S. A. Richardson, and R. G. Sloan. 2006. The Relation between Corporate Financing Activities, Analysts' Forecasts, and Stock Returns. Journal of Accounting and Economics 42:53-85.

Brav, A., C. Geczy, and P. A. Gompers. 2000. Is the Abnormal Return Following Equity Issuances Anomalous? Journal of Financial Economics 56:209-49.

Brown, S. J., W. N. Goetzmann, T. Hiraki, N. Shiraishi, and M. Watanabe. 2008. Investor Sentiment in Japanese and U.S. Daily Mutual Fund Flows. NBER Working Paper No. W9470.

Butler, A. W., G. Grullon, and J. P. Weston. 2005. Can Managers Forecast Aggregate Market Returns?. Journal of Finance 60:963-86.

Carhart, M. M. 1997. On Persistence in Mutual Fund Performance. Journal of Finance 52:57-82.

Chen, L., and L. Zhang. 2010. A Better Three-Factor Model That Explains More Anomalies. Working Paper, University of Michigan.

Cooper, M. J., H. Gulen, and M. J. Schill. 2008. Asset Growth and the Cross-Section of Stock Returns. Journal of Finance 63:1609-51.

Daniel, K. D., D. Hirshleifer, and A. Subrahmanyam. 1998. Investor Psychology and Security Market Underand Over-Reactions. Journal of Finance 53:1839-86.

- 2001. Overconfidence, Arbitrage, and Equilibrium Asset Pricing. Journal of Finance 56:921-65.

University.

2005. Investor Psychology and Tests of Factor Pricing Models. Working Paper, Northwestern

Daniel, K. D., and S. Titman. 1997. Evidence on the Characteristics of Cross-Sectional Variation in Common Stock Returns. Journal of Finance 52:1-33. 2006. Market Reactions to Tangible and Intangible Information. Journal of Finance 61:1605-44.

Eckbo, B. E., R. W. Masulis, and O. Norli. 2000. Seasoned Public Offerings: Resolution of the "New Issues Puzzle." Journal of Financial Economics 56:251-91. 
Fama, E. F., and K. R. French. 1992, The Cross-Section of Expected Stock Returns. Journal of Finance $47: 427-65$ $33: 3-56$.

1993. Common Risk Factors in the Returns on Stocks and Bonds. Journal of Financial Economics 1997. Industry Costs of Equity. Journal of Financial Economics 43:153-93.

Ferguson, M. F., and R. L. Shockley. 2003. Equilibrium "Anomalies." Journal of Finance $58: 2549-80$.

Ferson, W. E., and C. R. Harvey. 1991. The Variation of Economic Risk Premiums. Journal of Political Economy 99:385-415.

Gilchrist, S., C. P. Himmelberg, and G. Huberman. 2005. Do Stock Price Bubbles Influence Corporate Investment? Journal of Monetary Economics 52:805-27.

Goetzmann, W. N., and M. Massa. 2005. Disposition Matters: Volume, Volatility and Price Impact of a Behavioral Bias. NBER Working Paper No. W9499.

Graham, J. R., and C. R. Harvey. 2001. The Theory and Practice of Corporate Finance: Evidence from the Field. Journal of Financial Economics 60:187-243.

Griffin, J. M., and M. L. Lemmon. 2002. Book-to-Market Equity, Distress Risk, and Stock Returns. Journal of Finance 57:2317-36.

Grundy, B., and J. S. Martin. 2001. Understanding the Nature of the Risks and the Source of the Rewards to Momentum Investing. Review of Financial Studies 14:29-78.

Hirshleifer, D., K. Hou, S. H. Teoh, and Y. Zhang. 2004. Do Investors Overvalue Firms with Bloated Balance Sheets? Journal of Accounting and Economics 38:297-331.

Hou, K. 2007. Industry Information Diffusion and the Lead-Lag Effect in Stock Returns. Review of Financial Studies 20:1113-38.

Hou, K., L. Peng, and W. Xiong. 2007. $R^{2}$ and Momentum. Working Paper, Ohio State University.

Ikenberry, D., J. Lakonishok, and T. Vermaelen. 1995. Market Underreaction to Open Market Share Repurchases. Journal of Financial Economics 39:181-208.

Jegadeesh, N. 2000. Long-Run Performance of Seasoned Equity Offerings: Benchmark Errors and Biases in Expectations. Financial Management 9:5-30.

Keim, D. B. 1983. Size Related Anomalies and Stock Return Seasonality: Further Evidence. Journal of Financial Economics 12:13-32.

Kyle, A., and W. Xiong. 2001. Contagion as a Wealth Effect. Journal of Finance 56:1401-40.

Lakonishok, J., and T. Vermaelen. 1990. Anomalous Price Behavior around Repurchase Tender Offers. Journal of Finance 45:455-77.

Lee, C., A. Shleifer, and R. Thaler. 1991. Investor Sentiment and the Closed-End Fund Puzzle. Journal of Finance 46:75-109.

Lewellen, J., and S. Nagel. 2006. The Conditional CAPM Does Not Explain Asset-Pricing Anomalies. Journal of Financial Economics 82:289-314.

Lewellen, J., S. Nagel, and J. Shanken. 2010. A Skeptical Appraisal of Asset-Pricing Tests. Journal of Financial Economics 96:175-94.

Loughran, T. 1997. Book-to-Market across Firm Size, Exchange, and Seasonality: Is There an Effect? Journal of Financial and Quantitative Analysis 32:249-68.

Loughran, T., and J. Ritter. 1995. The New Issues Puzzle. Journal of Finance 50:23-52. 
. 2000. Uniformly Least Powerful Tests of Market Efficiency. Journal of Financial Economics 55: $361-89$.

Loughran, T., J. Ritter, and K. Rydqvist. 1994. Initial Public Offerings: International Insights. Pacific-Basin Finance Journal 2:165-99.

Loughran, T., and A. M. Vijh. 1997. Do Long-Term Shareholders Benefit from Corporate Acquisitions? Journal of Finance 52:1765-90.

Lowry, M. 2003. Why Does IPO Volume Fluctuate So Much? Journal of Financial Economics 67:3-40.

Lyandres, E., L. Sun, and L. Zhang. 2008. The New Issues Puzzle: Testing the Investment-Based Explanation. Review of Financial Studies 21:2417-48.

MacKinlay, A. C. 1995. Multifactor Models Do Not Explain Deviations from the CAPM. Journal of Financial Economics 38:3-28.

Michaely, R., R. H. Thaler, and K. L. Womack. 1995. Price Reactions to Dividend Initiations and Omissions: Overreaction or Drift? Journal of Finance 50:573-608.

Newey, W. K., and K. D. West. 1987. A Simple, Positive Semi-Definite, Heteroskedasticity and Autocorrelation Consistent Covariance Matrix. Econometrica 55:703-8.

Polk, C., and P. Sapienza. 2009. The Stock Market and Corporate Investment: A Test of Catering Theory. Review of Financial Studies 22:187-217.

Pontiff, J., and A. Woodgate. 2008. Shares Outstanding and Cross-Sectional Returns. Journal of Finance 63:921-45.

Ritter, J. 1984. The "Hot Issue" Market of 1980. Journal of Business 57:215-40.

Schultz, P. 2003. Pseudo Market Timing and the Long-Run Underperformance of IPOs. Journal of Finance 58:483-517.

Sloan, R. 1996. Do Stock Prices Fully Reflect Information in Accruals and Cash Flows about Future Earnings? Accounting Review 71:289-315.

Spiess, D. K., and J. Affleck-Graves. 1995. Underperformance in Long-Run Stock Returns Following Seasoned Equity Offerings. Journal of Financial Economics 38:243-68.

1999. The Long-Run Performance of Stock Returns Following Debt Offers. Journal of Financial Economics 54:45-73.

Stein, J. 1996. Rational Capital Budgeting in an Irrational World. Journal of Business 69:429-55.

Stigler, G. J. 1964. Public Regulation of the Securities Markets. Journal of Business 37:117-42.

Teoh, S. H., I. Welch, and T. J. Wong. 1998a. Earnings Management and the Long-Term Market Performance of Initial Public Offerings. Journal of Finance 53:1935-74.

1998b. Earnings Management and the Underperformance of Seasoned Equity Offerings. Journal of Financial Economics 50:63-99.

Titman, S., J. K. C. Wei, and F. Xie. 2004. Capital Investment and Stock Returns. Journal of Financial and Quantitative Analysis 39:677-701.

Zhang, L. 2005. The Value Premium. Journal of Finance 60:67-103. 